\title{
Cyclical and institutional determinants of annual trade union growth and decline in Ireland: evidence from the DUES data series
}

\author{
WILLIAM K. ROCHE AND JOE LARRAGY
}

ABSTRACT Attempts to apply the influential Bain-Elsheikh model to annual trade union growth and decline in Ireland have produced puzzling results. This paper rejects existing interpretations of such results by economists and offers an alternative explanation which is theoretically and empirically more satisfactory. While strong evidence is found that variations in labour market slackness affect opportunity to unionize, there is no evidence that they directly affect employees' or employers' dispositions towards unionization. The paper establishes that the peculiarities of labour market and institutional structure and development in Ireland provide a severe test of models developed on the basis of the experience of the major Western nations.

\section{INTRODUCTION}

Since the early 1980s trade unions in Ireland have experienced a sharp decline in membership. Between 1980 and 1985 in the region of 51,000 members were lost. In fact the recent decline in membership has been so dramatic and sustained that it represents the most serious setback experienced by Irish unions since the 1920s. Figures 1(a) and 1(b) present the trend in aggregate union membership and inter-year rates of growth and decline since the early 1930 s. While it appears from the graphs that Irish unions have tended to decline in periods of recession and to recover in periods of economic buoyancy, the figures beg more questions than they resolve. What aspects of economic buoyancy or recession are most important in influencing the trend of union growth and decline? In what manner do economic trends influence employees' decisions regarding whether they should join a trade union or remain unionized? How closely is the trend of unionization in any year related to the state of the economy, given that membership growth rates recorded during the 1960 s and 1970 s seem relatively modest considering the unprecedented economic prosperity enjoyed by Ireland for much of this period? Have other factors, not related in any direct way to economic activity, also influenced the trend of unionization?

\section{ANNUAL VARIATIONS IN TRADE UNION GROWTH AND DECLINE}

In recent years much debate and research on short-run union membership growth, and specifically on its relationship to the economic or business cycle, has focused on the 'BainElsheikh' model, developed in a well-known study of union growth in four countries (Bain and Elsheikh, 1976). Drawing heavily, if critically, on earlier historical and econometric work on the determinants of union growth, Bain and Elsheikh develop and estimate the following theoretical model:

$$
\begin{gathered}
\Delta \mathrm{M}_{\mathrm{t}}=\beta_{0}+\beta_{1} \Delta \mathrm{W}_{\mathrm{t}}+\beta_{2} \Delta \mathrm{P}_{\mathrm{t}}+\beta_{3} \mathrm{U}_{\mathrm{t}}+ \\
\beta_{4} \mathrm{D}_{\mathrm{t}-1}+\epsilon_{\mathrm{t}}
\end{gathered}
$$

where $\Delta \mathrm{M}_{\mathrm{t}}$, the inter-year proportionate rate of change in trade union growth is a linear effect of $\Delta \mathrm{W}_{\mathrm{t}}$, the inter-year rate of change in money wages, $\Delta \mathrm{P}_{\mathrm{t}}$, the annual rate of price inflation, $U_{t}$, the level of unemployment, $D_{t-1}$, the level of trade union density, lagged one year (and 

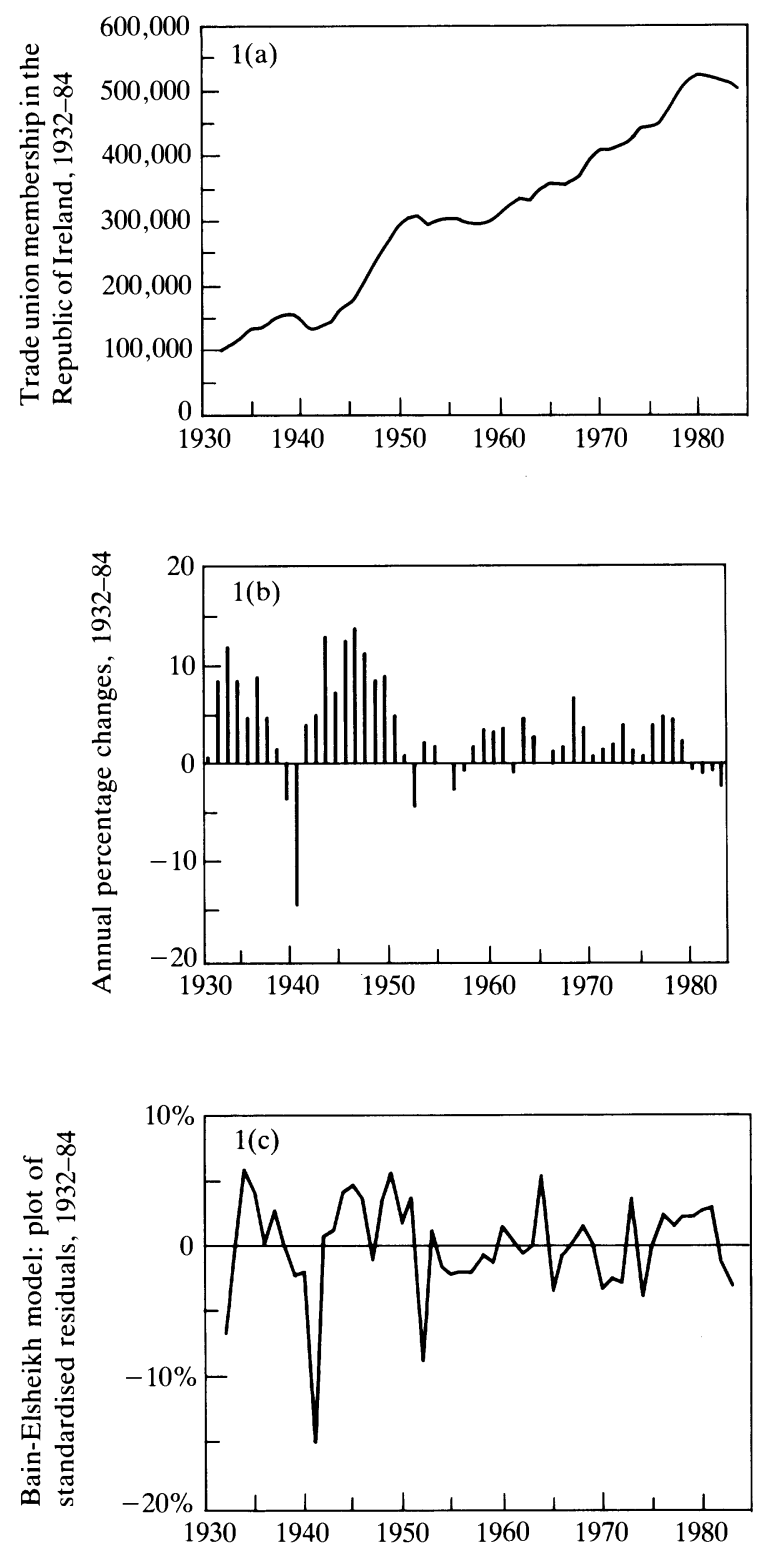

FIGURE 1 Trade union growth in Ireland

measured as membership over all employees at work legally entitled to join unions plus the unemployed), and $\epsilon_{\mathrm{t}}$, a random error term. ${ }^{1}$ The expected signs on the coefficients are as follows:

$$
\beta_{1}, \beta_{2}>0>\beta_{3}, \beta_{4}
$$

Variations in money wages are held to affect the degree to which potential and existing trade union members credit unions with success in negotiating pay rises. Variations in retail prices are believed to influence employees' propensity to enter or remain in unions through the threat posed to living standards. Thus, the higher the rate of rise in prices, other things being equal, the more unions are held to benefit from the 'threat effect' of inflation. Moreover, rising prices, it is argued, usually reflect business buoyancy, and, as such, $\Delta \mathrm{P}_{\mathbf{t}}$ also captures, a 
'prosperity effect': that is, variations in the degree to which employers will possess the power or inclination to resist the spread of unionization. In times of business prosperity employer resistance to unionization will decrease as employers become more concerned to avoid disruption to business and less concerned about the possible effect of unions on costs.

The level and/or the rate of change in unemployment is expected to influence short-run changes in the rate of membership growth because it may affect the costs and benefits associated with joining a union or remaining a union member. Unions may provide few services of value to the unemployed, with the result that the cost of becoming or remaining a member if unemployed may greatly outweigh the benefits. In a slack labour market employers are also more likely to resist unionization and this may increase the cost of joining or remaining in benefit for those in employment. Finally, union growth is expected to be inversely related to the level of union density because, as the latter rises, the marginal cost to unions of recruiting additional members will increase, as well, possibly, as the marginal disinclination of remaining employees to unionize. These factors combine to give the so-called 'saturation effect' imposed by rising density on further membership growth.

Clearly the Bain-Elsheikh basic model cannot claim to be a complete model of annual trade union growth and decline. The model is focused primarily on business-cycle influences which affect short-run variations in aggregate union membership. A complete aggregate-level model would also have to include two other major types of influence. It is reasonably generally established that the probability of being unionized varies in accordance with a variety of socio-demographic factors. For example, workers in large organizations tend, other things being equal, to be more highly unionized than workers in small organizations; blue-collar workers tend to be more highly unionized than white-collar workers; men tend to be more highly unionized than women. These factors aggregate into important differences in levels of unionization between industries. Changes in the distribution of the work-force across industrial groups will then affect the trend in aggregate unionization, depending on the direction those changes take. As such, we can speak of aggregate structural influences on union growth and decline, which of their nature, tend to be marginal from year to year and only to become apparent in the long-run trend of unionization. Finally, it is also apparent that a variety of institutional influences can affect the trend in union membership. Laws may be passed which either facilitate or hinder the organizing efforts of unions; the primary level at which collective bargaining is conducted in a country might affect the fortunes of unions through its effect on perceptions of union influence. The political composition of the party or parties in government in different periods may also influence unionization. Left-wing and social democratic governments might be expected to be broadly supportive of union power and influence, while liberal and right-wing governments are likely to foster and reflect a more hostile climate for unions.

While the use of a density measure to capture the 'saturation effect' in the Bain-Elsheikh model, takes account of the impact of structural change on union membership, it does so only in a very rough manner. In empirical estimation, much of the impact of structural change is necessarily disguised in the constant term of the model. Similarly, in applications of the model to some countries, Bain and Elsheikh try to allow for what we have called institutional influences through the use of binary or dummy variables. Such effects are not theorized in any systematic manner.

Such problems aside, the model produced satisfactory results when estimated over long periods for the United Kingdom (1893-1970), the United States (1897-1970), Australia (19071969) and Sweden (1914-1970) (Bain and Elsheikh, 1976: 87-115). Given the parsimonious character of the model and its apparent ability to account for annual union growth and decline in nations with strikingly different trade union traditions, there seems to be no reason a priori why it cannot be used effectively as a baseline model with which to explore influences on trade union growth and decline in Ireland. 
TABLE 1 Trade union growth in Ireland, 1932-1984: The 'Bain-Elsheikh Model' and WS ${ }_{t}^{(\mathrm{a})}$

\begin{tabular}{|c|c|c|c|c|c|}
\hline Equation & 1.1 & 1.2 & 1.3 & 1.4 & 1.5 \\
\hline Method & OLS & OLS & OLS & OLS & CORC \\
\hline $\mathbf{R}^{2}$ & $0.4502^{*}$ & $0.4907^{*}$ & $0.4546^{*}$ & $0.6523 *$ & $0.6516^{*}$ \\
\hline $\mathrm{F}$ & $9 \cdot 8275$ & $11 \cdot 3195$ & $10 \cdot 0001$ & $22 \cdot 5972$ & 21.9735 \\
\hline $\begin{array}{l}\text { DW } \\
\text { p }\end{array}$ & $1.71 \dagger$ & $1.76 \dagger$ & $1.73 \dagger$ & $1 \cdot 58 \ddagger$ & $\begin{array}{l}1 \cdot 81 \dagger \\
0 \cdot 14\end{array}$ \\
\hline Constant & $\begin{array}{l}10 \cdot 1381^{*} \\
(3 \cdot 627)\end{array}$ & $\begin{array}{l}12 \cdot 1839^{*} \\
(3 \cdot 881)\end{array}$ & $\begin{array}{l}9 \cdot 8396^{*} \\
(5 \cdot 567)\end{array}$ & $\begin{array}{l}10 \cdot 9113^{*} \\
(7 \cdot 846)\end{array}$ & $\begin{array}{l}9.9902 * \\
(7 \cdot 579)\end{array}$ \\
\hline$\Delta \mathrm{W}_{\mathrm{t}}$ & $\begin{array}{l}0 \cdot 7447 * \\
(5 \cdot 067)\end{array}$ & $\begin{array}{l}0 \cdot 7464^{*} \\
(5 \cdot 247)\end{array}$ & $\begin{array}{l}0.7561^{*} \\
(5 \cdot 259)\end{array}$ & $\begin{array}{l}0 \cdot 6406^{*} \\
(5 \cdot 507)\end{array}$ & $\begin{array}{l}0 \cdot 5751^{*} \\
(5 \cdot 144)\end{array}$ \\
\hline$D_{t-1}$ & $\begin{array}{l}-0.2358^{*} \\
(-4.098)\end{array}$ & $\begin{array}{l}-0.2603^{*} \\
(-4 \cdot 489)\end{array}$ & $\begin{array}{l}-0 \cdot 2365^{*} \\
(-4 \cdot 203)\end{array}$ & $\begin{array}{l}-0.2571^{*} \\
(-5 \cdot 721)\end{array}$ & $\begin{array}{l}-0 \cdot 2584 * \\
(-5 \cdot 508)\end{array}$ \\
\hline$\Delta \mathrm{P}_{\mathrm{t}}$ & $\begin{array}{l}-0.5815^{*} \\
(-4 \cdot 289)\end{array}$ & $\begin{array}{l}-0.5876^{*} \\
(-4 \cdot 491)\end{array}$ & $\begin{array}{l}-0.5913^{*} \\
(-4 \cdot 809)\end{array}$ & $\begin{array}{l}-0.4509 * \\
(-4.437)\end{array}$ & $\begin{array}{l}-0 \cdot 4446^{*} \\
(-4 \cdot 391)\end{array}$ \\
\hline $\mathrm{U}_{\mathrm{t}}$ & $\begin{array}{c}-0.0384 \\
(-0 \cdot 206)\end{array}$ & & & & \\
\hline$U_{t-1}$ & & $\begin{array}{c}-0.1336 \\
(-0.639)\end{array}$ & & & \\
\hline$\Delta U_{t}$ & & & $\begin{array}{c}-0.0176 \\
(-0.650)\end{array}$ & & \\
\hline $\mathrm{WS}_{\mathrm{t}}$ & & & & $\begin{array}{l}-16 \cdot 7525^{*} \\
(-5 \cdot 306)\end{array}$ & $\begin{array}{l}-16 \cdot 3816^{*} \\
(-5 \cdot 805)\end{array}$ \\
\hline
\end{tabular}

Note: (a) In this and subsequent tables, figures in brackets are (one-tailed) 't-ratios'. * denotes a coefficient which is significantly different from zero at the $1 \%$ level; $\dagger$ indicates the absence of first-order autocorrelation at the $1 \%$ level; and $\ddagger$ indicates an inconclusive Durbin-Watson statistic.

\section{ESTIMATING A BASIC MODEL}

Major data problems are encountered in estimating this model in the Irish case. The steps we have followed to resolve these problems, particularly as they affect the dependent variable, are outlined at length in another paper (Roche and Larragy, 1989: 5-9). Suffice it here to note that we have not relied on previous published aggregate official or union statistics but have instead built up new aggregates from an examination of extant public and other records relating to every trade union known to have existed in Ireland since 1929. Given the availability of data, empirical estimation must be restricted to the period from 1930 or 1932 to 1984 , depending on how variables are specified.

The basic Bain-Elsheikh model is estimated in equations 1.1 to 1.3 of Table 1 . The method of estimation used is ordinary least squares regres- sion (OLS). Where there is evidence of autocorrelation, or where the Durbin-Watson statistic is inconclusive, equations are re-estimated to correct for autocorrelation, using the CochraneOrcutt iterative procedure (CORC) ${ }^{2}$ It appears from these equations that the basic model performs less than satisfactorily. The $\mathrm{R}^{2} \mathrm{~s}$ for the equations indicate that the model explains less than 50 per cent of the annual variation in union growth. Wage trends and the level of union density do appear to have the effects postulated. However, several of the parameters fail to register the effects postulated in the Bain-Elsheikh model. Equations 1.1 to 1.3 indicate that the annual rate of unemployment fails to exert a significant effect on union growth in Ireland, whether introduced as a level $\left(U_{t}\right)$ or as a rate of change $\left(\Delta U_{t}\right)$, and irrespective of whether current or lagged values are employed. The reasons 
why there appears to be no concurrent linear association between the measured rate of unemployment and the rate of union growth in Ireland will be considered later in the paper. Further, all equations point to a highly significant negative association in the Irish case between inflation and union growth. ${ }^{3}$

\section{STAGFLATION AND POTENTIAL UNION MEMBERSHIP}

An examination of the estimated residuals of the basic model, plotted in Figure 1(c), suggests a number of underlying problems. First, it is clear that a dramatic and unexpected decline in membership was recorded during 1941. This outlier obviously depresses significantly the goodness of fit of the model and reflects the impact on union growth of exceptional circumstances. During 1941, the Government attempted to control inflation by introducing legislation which imposed a virtual freeze on wages (the Wages Standstill Order). This effectively hamstrung unions with regard to wage bargaining, and thus probably accounts in large measure for the dramatic fall in union membership. The passing of the Trade Union Act 1941 in the teeth of strong trade union opposition may also have contributed to the membership crisis. The Act introduced a system of licensing for unions and led to the atrophy or dissolution of a number of organizations which had little possibility of meeting the conditions necessary to qualify for a licence. It is important, therefore, to take account of the exceptional institutional circumstances of 1941 in estimating the model, either by excluding this year entirely, or by allowing for the circumstances of 1941 in the model by means of a binary or dummy variable. The latter procedure is followed in equations 1.4-1.5, and all subsequent equations, where $\mathrm{WS}_{\mathrm{t}}$ defines the relevant dummy variable. It is clear that allowing for the exceptional circumstances of that year increases the explanatory power of the basic model. Equation 1.5, for example, which combines $\mathrm{WS}_{\mathrm{t}}$ and the significant variables from the three earlier equations, and which employs the CORC estimating procedure, accounts for some 65 per cent of the variance in inter-year union growth.
While a respectable fit is thus achieved by adjusting for the exceptional circumstances of 1941, Figure 1(c) also indicates that when the model is fitted the residuals obtained are clustered. These clusters suggest that relevant explanatory variables have been omitted from the model and that the coefficients of the terms in the basic model are thereby biased and unreliable. This problem has an important bearing on the perverse negative sign obtained on the price coefficient.

The first point that has to be noted in this regard is that whereas Bain and Elsheikh suggest that inflation will usually occur in periods of economic prosperity, it appears that in Ireland the opposite has more usually been the case. The highest inflationary peaks recorded between 1930 and 1984 have, in fact, occurred in periods of economic recession. ${ }^{4}$ Three such-stagflationary-peaks are particularly striking: the first between 1940 and 1943 when annual inflation varied between $10 \cdot 2$ and $15 \cdot 2$ per cent; the second following the first oil crisis between 1973 and 1977 when annual price rises varied between 11.4 and 20.9 per cent; and the third between 1979 and 1983 when inflation varied from $10 \cdot 5$ to $20 \cdot 5$ per cent.

Figure 2 brings out the recessionary character of major inflationary peaks in Ireland since the 1930 s by plotting the annual rate of price changes against a measure of labour market slackness: the annual rate of change in the level of employment. Regression analysis over different periods of years indicated that the significance of $\Delta \mathrm{P}_{t}$ in the basic Bain-Elsheikh model in fact depended on these inflationary peaks. In short, the conclusion must be that in the Irish case $\Delta \mathrm{P}_{\mathrm{t}}$ entered in the basic model tends to proxy-at least in part-not the prosperity effect postulated by Bain and Elsheikh but, on the contrary, the drag imposed on union growth by periods of stagflation and labour market slackness. In such periods the pool of potential members available to unions is reduced, while employees' propensity to unionize may also fall in response to labour market slackness, as is suggested by Bain and Elsheikh. That the price term in the model picks up labour market slackness, even when an unemployment term is also included, points to 


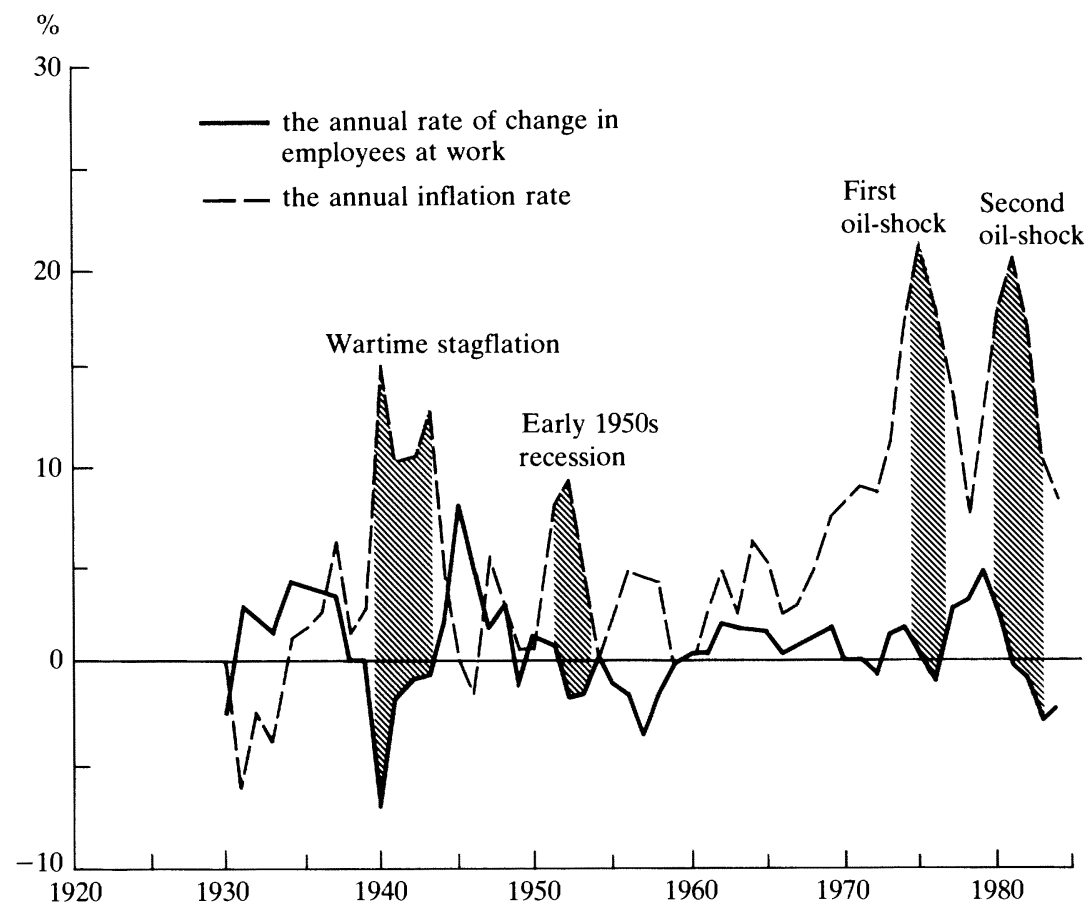

FIGURE 2 The trend in inflation superimposed on the trend in employees at work, Ireland 1930-1984

the unreliability of the latter as a measure of labour market slackness in the Irish case.

It seems advisable, then, to introduce a potential membership variable into the model directly, in order to examine whether it alters the results on the price coefficient, affects the tendency for residuals to cluster and so reduces the risk of bias in the coefficients and of obtaining spurious results. ${ }^{5}$

A theoretical problem that then arises, however, is how potential trade union membership should be specified. One alternative is to follow Bain and Elsheikh by specifying potential membership as employees in employment plus the unemployed. It seems questionable that this represents a realistic definition of potential membership in the Irish (or, indeed, the British) case, whether viewed from the perspective of employees or from that of the unions which seek to recruit them. For what has characterized Irish trade unions, some recent initiatives notwithstanding, is a lack of concern with recruiting the unemployed and a concentration of organizing initiatives and union services on those in employment.

If we accept, therefore, that the unemployed cannot be regarded in any significant sense as having formed part of the constituency or potential membership of Irish trade unions over the period covered by this study, it follows that the rate of change in employees at work and not the rate of change in the work-force should be used as a measure of annual changes in potential trade union membership. The narrower definition of potential membership should also, of course, be adopted in defining trade union density.

The importance of this theoretical question becomes clear when models are fitted incorporating alternative potential membership terms and alternative specifications of union density. In the equations reported in Table $2, \Delta \mathrm{E}_{\mathrm{t}}$ and $\Delta \mathrm{WF}_{\mathrm{t}}$ denote the annual rates of change respectively of employees in employment and the employee work-force; $D_{t-1}$ denotes lagged density defined with the employee work-force as 
EUROPEAN SOCIOLOGICAL REVIEW

TABLE 2 Trade union growth in Ireland, 1930-1984: Results of alternative specifications of changes in potential membership and density, combined with model estimation over different periods of years

\begin{tabular}{|c|c|c|c|c|}
\hline Equation & 2.1 & 2.2 & 2.3 & 2.4 \\
\hline Period & $1933-84$ & $1933-84$ & $1930-84$ & $1930-84$ \\
\hline Method & OLS & OLS & OLS & CORC \\
\hline $\mathbf{R}^{2}$ & $0.7990^{*}$ & $0 \cdot 8028^{*}$ & $0 \cdot 6976^{*}$ & $0 \cdot 6379 *$ \\
\hline $\mathrm{F}$ & $29 \cdot 8092$ & $30 \cdot 5379$ & $22 \cdot 6063$ & $16 \cdot 9091$ \\
\hline DW & $2 \cdot 10 \dagger$ & $2 \cdot 07 \dagger$ & $1 \cdot 58 \ddagger$ & $1.78 \dagger$ \\
\hline Constant & $\begin{array}{l}13 \cdot 9291^{*} \\
(7 \cdot 745)\end{array}$ & $\begin{array}{l}9 \cdot 8828^{*} \\
(5 \cdot 685)\end{array}$ & $\begin{array}{l}7 \cdot 7850^{*} \\
(5 \cdot 875)\end{array}$ & $\begin{array}{l}6 \cdot 5060^{*} \\
(5 \cdot 038)\end{array}$ \\
\hline$\Delta \mathrm{W}_{\mathrm{t}}$ & $\begin{array}{c}0 \cdot 6668^{*} \\
(4 \cdot 651)\end{array}$ & $\begin{array}{c}0 \cdot 4166^{*} \\
(4 \cdot 034)\end{array}$ & $\begin{array}{l}0 \cdot 3826^{*} \\
(3 \cdot 242)\end{array}$ & $\begin{array}{l}0.3531 * \\
(2.969)\end{array}$ \\
\hline$D_{t-1}$ & $\begin{array}{l}-0.2598^{*} \\
(-7.055)\end{array}$ & & & \\
\hline $\mathrm{DE}_{\mathrm{t}-1}$ & & $\begin{array}{l}-0.2033^{*} \\
(-5.988)\end{array}$ & $\begin{array}{l}-0 \cdot 1723 * \\
(-4 \cdot 402)\end{array}$ & $\begin{array}{l}-0 \cdot 1732^{*} \\
(-3.901)\end{array}$ \\
\hline$\Delta \mathrm{WF}_{\mathrm{t}}$ & $\begin{array}{l}0 \cdot 6668^{*} \\
(4 \cdot 651)\end{array}$ & & & \\
\hline$\Delta \mathrm{E}_{\mathrm{t}}$ & & $\begin{array}{c}0 \cdot 7550^{*} \\
(4 \cdot 800)\end{array}$ & $\begin{array}{c}0 \cdot 7824^{*} \\
(4 \cdot 349)\end{array}$ & $\begin{array}{c}0 \cdot 6608^{*} \\
(3 \cdot 351)\end{array}$ \\
\hline$\Delta \mathrm{P}_{\mathrm{t}}$ & $\begin{array}{l}-0 \cdot 2763^{*} \\
(-2 \cdot 906)\end{array}$ & $\begin{array}{l}-0.2633^{*} \\
(-2.759)\end{array}$ & $\begin{array}{l}-0 \cdot 1752 \\
(-1 \cdot 729)\end{array}$ & $\begin{array}{c}-0.1733 \\
(-1.551)\end{array}$ \\
\hline $\mathrm{U}_{\mathrm{t}}$ & $\begin{array}{l}-0 \cdot 2958^{*} \\
(-2 \cdot 419)\end{array}$ & $\begin{array}{c}-0.0089 \\
(-0.078)\end{array}$ & & \\
\hline $\mathrm{WS}_{\mathrm{t}}$ & $\begin{array}{l}-15 \cdot 9834^{*} \\
(-6 \cdot 360)\end{array}$ & $\begin{array}{l}-16 \cdot 4015^{*} \\
(-6 \cdot 631)\end{array}$ & $\begin{array}{l}-15 \cdot 9993^{*} \\
(-5 \cdot 435)\end{array}$ & $\begin{array}{l}-15 \cdot 7322^{*} \\
(-5 \cdot 812)\end{array}$ \\
\hline
\end{tabular}

denominator, and $\mathrm{DE}_{\mathrm{t}-1}$ denotes lagged density defined, with employees at work as denominator. ${ }^{6}$ Given the data available, models incorporating $D_{t-1}$ and $\Delta W F_{t}$ specifications of density and changing potential membership terms can be fitted only to data for the period 1933-84. Equations 2.1 and 2.2 of Table 2 present the results of models incorporating alternative specifications of changing potential membership and density covering the period $1933-84$. It is clear that both potential membership terms and both density specifications are significant and correctly signed. $\Delta \mathrm{P}_{\mathrm{t}}$ remains significant at the 99 per cent level irrespective of the manner in which these variables are specified. The inclusion of $\Delta W F_{t}$ and $\Delta \mathrm{E}_{\mathrm{t}}$ in the model increases the overall goodness of fit, though neither specification is markedly superior in this respect. The Durbin-Watson statistics approach
$2 \cdot 0$, indicating that the level of autocorrelation among the residuals has been reduced. The weak and insignificant coefficient on the unemployment term in equations 2.1 and 2.2 underlines the lack of a concurrent linear relationship between union growth and the measured level of unemployment in Ireland.

In models including $\Delta \mathrm{E}_{\mathrm{t}}$ and $\mathrm{DE}_{\mathrm{t}-1}$, the significance of $\Delta \mathrm{P}_{\mathrm{t}}$ is found to be very dependent on the cases or years included in the regressions. When models including these terms-and omitting the insignificant unemployment term-are fitted over the periods $1932-84,1931-84$, or $1930-84, \Delta \mathrm{P}_{\mathrm{t}}$ fails to reach significance at the chosen confidence level. The significance of other terms is unaffected by the addition or exclusion of these cases. ${ }^{7}$ Equation 2.3 fits a model which includes $\Delta \mathrm{E}_{\mathrm{t}}$ and $\mathrm{DE}_{\mathrm{t}-1}$, but excludes the insignificant unemployment term, 
over the period 1930-84. And equation 2.4 estimates the same model adjusting for the possibility of autocorrelation. It is clear from both sets of results that the overall explanatory power of the model declines when $1930-32$ is included in model estimation. It is also clear that the only coefficient which becomes insignificant is $\Delta \mathrm{P}_{\mathrm{t}}$.

An important conclusion can be drawn from these findings. The effect of changes in price levels on the rate of change in union membership is very much less consistent than the effect of the other variables that have been shown to influence the annual rate of unionization over the period since 1930. In other words, the significant ' $t$ ratio' on the price term of equation 2.2 cannot be accepted uncritically as indicating that rises in the price level have generally or reasonably consistently, and in broadly linear manner, exerted a drag on the rate of union growth in Ireland. Rather, it must be concluded that an analysis of the properties of the price coefficient suggests that the price effect evident in equations 2.1 and 2.2 is something of a statistical artifact which is highly sensitive to the cases included in model estimation.

While the actual effect of prices on the rate of union growth between 1930-84 is thus revealed as erratic and, in this sense, insignificant, it has to be recognized at the same time that the years 1931 and 1932 represent 'outliers' in the relationship between the price trend and the rate of union growth. ${ }^{8}$ Yet there seems no good reason to exclude these outlying years from model estimation; on the contrary, a theoretical reason can indeed be given for their inclusion. The period 1930-32 was unique in the overall period 1930-84 in that it represented a period of deflationary recession. Looked at over the longer-run, these years were the tail-end of a deflationary slump which extended back to the early 1920s.

From the data available on trends in union membership during the 1920 s, it is clear that the level of unionization fell drastically. If data were available to include this earlier period in model estimation, it is therefore very probable that the results obtained would further undermine the negative price effect on union growth apparent in tests of the Bain-Elsheikh model and equation 2.2. Furthermore, anticipating a theme to be developed next, when a dummy variable is included in our respecified model to take account of the cluster of positive residuals between 1946-52, $\Delta \mathrm{P}_{\mathrm{t}}$ loses significance if we drop cases and test the model, for example, over 1934-84 or 1935-84. This provides further evidence for the inconsistency of the effect of changing prices on the level of unionization.

It can be concluded, therefore, that changes in the price level have not had a consistent linear effect on the rate of union growth in Ireland since 1930, and that this can be attributed at least in part to the recessionary character of periods of highest inflation in Ireland. Any increased propensity towards unionization there may have been in times of high inflation would thus have been counterbalanced by growing labour market slackness during these periods. ${ }^{9}$ This of course still assumes that Irish employees have reasonably consistently turned towards unions through a 'threat effect' in periods of high inflation. As will be seen later in the paper, there is in fact no evidence to support such an effect in the Irish case. The finding also still leaves open the important theoretical question of the manner in which variations in labour market conditions affect union growth and decline. It may simply be that periods of buoyancy and recession influence union growth through their effect on levels of employment and thus on the pool of potential union members. Bain and Elsheikh propose that the business cycle also, and more interestingly, affects employees' propensity to unionize through its effect on employer and employee behaviour: in times of prosperity employers adopt a softer stance towards unions and employees have less reason to fear that union membership will have negative consequences. Before giving further consideration to these important questions, it is first necessary to deal with further institutional complexities that arise in the Irish case.

\section{THE TRANSITION FROM WAGE CONTROL TO FREE COLLECTIVE BARGAINING}

Figure 1(c) shows that the estimated residuals that arise from fitting the basic model contain a cluster of positive values for the period from the 
mid-1940s to the early 1950 s, significant in magnitude, if somewhat erratic in trend. This indicates that the model tends to under-predict union growth for this period because it omits factors which had an important effect on employees' propensity or opportunity to unionize during the immediate post-war years. It seems to us that the principle of these factors can be identified and their effects accounted for. However, they are not related to the business cycle in any meaningful sense, and must instead be understood in terms of the effects on early post-war unionization of the manner in which the Irish economy was managed during wartime.

The wage freeze introduced during 1941 was replaced by a wage tribunal system in April of the following year. While wage rises were permissible under this system, the tribunals moderated the trend in pay and held increases below the rate of inflation. A sharp acceleration in the rate of inflation during the War thus imposed a sharp squeeze on real wages. It appears that the system of wartime wage control had significant direct and indirect effects on the rate of trade union growth subsequent to its abolition and the return to free collective bargaining in 1946. Specifically, we would distinguish between three related effects of the system of wage control in operation between April 1941 and August 1946. First, the sharp general squeeze on real wages, which resulted from pay rises throughout the labour market lagging behind the rate of inflation, was responsible for the build up of generalized pressure for the restoration of pre-war living standards. ${ }^{10}$ Secondly, the abolition of wage control in August 1946 had the effect of synchronizing wage pressure throughout the trade union movement.

These factors combined to trigger 'rounds' of synchronized wage bargaining, or pay rounds, as they were to become known. The advent of pay rounds represented a fundamental change in the manner in which wages were negotiated in Irish industrial relations. The early post-war rounds probably heightened significantly the 'credit effect' from which unions gain and hold members in that they gave union involvement in wage bargaining a degree of transparency not before attained. Finally, the removal of wage control also led to the establishment in 1946 of the Labour Court. The Court was to play an important role in institutionalizing pay rounds and also set about encouraging union recognition in sectors where employers had refused to countenance negotiations with trade unions. During its early years the proceedings of the Court were widely reported in the media, further enhancing the public profile unions were enjoying on the basis of their involvement in pay rounds. It is the combined effect of these developments, we would suggest, which explains in major degree the cluster of positive residuals for the post-war period evident in Figure 1(c).

The three strands in our explanation for dramatic union growth in the early post-war period cannot, however, be disentangled to allow estimation of their separate effects, as would be preferable. Nor, relatedly, can they be subsumed in any meaningful sense to the logic of the Bain-Elsheikh model. Bain and Elsheikh as we saw, seek to account for union growth in terms of the relatively straightforward current or recent effects of continuous economic variables. The situation which existed in the period following the abolition of wage control seems to us an example of a phase of significant economic and social discontinuity in the labour market, in which economic, social and institutional developments become, so to speak, convoluted and combine to produce rather unique effects. ${ }^{11}$ Drawing on our own earlier work, a group of researchers at Harvard have attempted to incorporate what we call the transition effect into a comprehensive multi-dimensional scale of Irish collective labour law; this is introduced into union growth models as a variable (see Pelletier, 1988). Elsewhere, we have presented a detailed theoretical and empirical critique of the scale (Roche and Larragy, 1989: 50-55). The method we use to estimate the 'transition effect' consequent on the shift from the wartime economy to normal labour market conditions is again to introduce a dummy variable. While the starting year of the transition effect values of this variable can then be specified as 1946, a problem arises regarding how we are to identify the terminating year. It would clearly be preferable if it could be determined a priori on theoretical grounds. Yet given the complexity of the effects 
TABLE 3 Trade union growth in Ireland, 1930-1984: the 'transition effect' dummy, alternative indicators of competitiveness, and price trends in periods of 'low' and 'high' unemployment

\begin{tabular}{|c|c|c|c|c|c|}
\hline Equation & 3.1 & 3.2 & 3.3 & 3.4 & 3.5 \\
\hline Period & $1930-84$ & $1930-84$ & 1930-84 & $1930-84$ & $1932-84$ \\
\hline Method & OLS & OLS & OLS & OLS & OLS \\
\hline $\mathbf{R}^{2}$ & $0.7867^{*}$ & $0.7875^{*}$ & $0.7874^{*}$ & $0 \cdot 7875^{*}$ & $0 \cdot 8315^{*}$ \\
\hline F & $29 \cdot 5118$ & 24.8929 & $24 \cdot 8708$ & $24 \cdot 8842$ & $31 \cdot 721$ \\
\hline DW & $1.82 \dagger$ & $1.84 \dagger$ & $1 \cdot 84 \dagger$ & $1 \cdot 84 \dagger$ & $2 \cdot 12 \dagger$ \\
\hline Constant & $\begin{array}{l}6 \cdot 0726^{*} \\
(5 \cdot 114)\end{array}$ & $\begin{array}{l}5.9215^{*} \\
(4 \cdot 744)\end{array}$ & $\begin{array}{l}5 \cdot 9013^{*} \\
(4 \cdot 132)\end{array}$ & $\begin{array}{l}5 \cdot 7845^{*} \\
(4 \cdot 178)\end{array}$ & $\begin{array}{l}7 \cdot 0451^{*} \\
(5 \cdot 979)\end{array}$ \\
\hline$\Delta \mathrm{W}_{1}$ & $\begin{array}{l}0 \cdot 2718^{*} \\
(2 \cdot 636)\end{array}$ & $\begin{array}{l}0 \cdot 2777^{*} \\
(2 \cdot 647)\end{array}$ & $\begin{array}{l}0 \cdot 2758^{*} \\
(2 \cdot 638)\end{array}$ & $\begin{array}{l}0 \cdot 2746^{*} \\
(2 \cdot 634)\end{array}$ & $\begin{array}{c}0 \cdot 2950^{*} \\
(3 \cdot 024)\end{array}$ \\
\hline $\mathrm{DE}_{\mathrm{t}-1}$ & $\begin{array}{l}-0 \cdot 1347^{*} \\
(-4 \cdot 006)\end{array}$ & $\begin{array}{l}-0 \cdot 1360^{*} \\
(-3 \cdot 876)\end{array}$ & $\begin{array}{l}-0 \cdot 1325^{*} \\
(-3 \cdot 664)\end{array}$ & $\begin{array}{l}-0 \cdot 1313^{*} \\
(-3 \cdot 561)\end{array}$ & $\begin{array}{l}-0 \cdot 1512 * \\
(-4 \cdot 691)\end{array}$ \\
\hline$\Delta \mathrm{E}_{\mathrm{t}}$ & $\begin{array}{l}0 \cdot 8320^{*} \\
(5 \cdot 437)\end{array}$ & $\begin{array}{l}0 \cdot 8431^{*} \\
(5 \cdot 388)\end{array}$ & $\begin{array}{c}0 \cdot 8434^{*} \\
(5 \cdot 367)\end{array}$ & $\begin{array}{c}0 \cdot 8451^{*} \\
(5 \cdot 364)\end{array}$ & $\begin{array}{c}0 \cdot 8277^{*} \\
(5 \cdot 638)\end{array}$ \\
\hline$\Delta \mathrm{P}_{\mathrm{t}}$ & $\begin{array}{c}-0.0978 \\
(-1.115)\end{array}$ & $\begin{array}{c}-0 \cdot 1158 \\
(-1 \cdot 183)\end{array}$ & $\begin{array}{c}-0 \cdot 1144 \\
(-1 \cdot 165)\end{array}$ & $\begin{array}{c}-0 \cdot 1147 \\
(-1 \cdot 178)\end{array}$ & \\
\hline $\mathrm{WS}_{\mathrm{t}}$ & $\begin{array}{l}-15 \cdot 7018^{*} \\
(-6 \cdot 284)\end{array}$ & $\begin{array}{l}-15 \cdot 5187^{*} \\
(-6 \cdot 072)\end{array}$ & $\begin{array}{l}-15 \cdot 5217^{*} \\
(-6 \cdot 056)\end{array}$ & $\begin{array}{l}-15 \cdot 5112^{*} \\
(-6 \cdot 054)\end{array}$ & $\begin{array}{l}-15 \cdot 7752^{*} \\
(-6 \cdot 914)\end{array}$ \\
\hline $\mathrm{T}$ & $\begin{array}{c}4.4694 * \\
(4 \cdot 479)\end{array}$ & $\begin{array}{l}4 \cdot 5520^{*} \\
(4 \cdot 443)\end{array}$ & $\begin{array}{l}4 \cdot 5662 * \\
(4 \cdot 404)\end{array}$ & $\begin{array}{c}4 \cdot 5825^{*} \\
(4 \cdot 394)\end{array}$ & $\begin{array}{c}4 \cdot 0036^{*} \\
(4 \cdot 303)\end{array}$ \\
\hline $\mathrm{Cl}_{\mathrm{t}}$ & & $\begin{array}{c}0 \cdot 0791 \\
(0 \cdot 430)\end{array}$ & & & \\
\hline$C 2_{t}$ & & & $\begin{array}{c}0 \cdot 1319 \\
(0 \cdot 390)\end{array}$ & & \\
\hline $\mathrm{C} 3_{\mathrm{t}}$ & & & & $\begin{array}{c}0 \cdot 1512 \\
(0 \cdot 415)\end{array}$ & \\
\hline$\Delta \mathrm{PG}_{\mathrm{t}}$ & & & & & $\begin{array}{c}-0 \cdot 1406 \\
(-1 \cdot 264)\end{array}$ \\
\hline$\Delta \mathrm{PS}_{\mathrm{t}}$ & & & & & $\begin{array}{c}-1 \cdot 1539 \\
(-1 \cdot 839)\end{array}$ \\
\hline
\end{tabular}

it is used to measure, this hardly seems possible. The termination year of the transition effect dummy (T) was set at 1952 on the basis of an examination of the cluster of residuals evident in Figure $1(\mathrm{c}) .{ }^{12}$ As is evident from equation 3.1 of Table 3, the inclusion of the dummy raises the explanatory power of the model and further reduces the effect and significance of $\Delta \mathrm{P}_{\mathrm{t}}$. The $\mathrm{R}^{2}$ rises to 0.79 and an $\mathrm{F}$ test confirms that the addition of $\mathrm{T}$ raises the explanatory power of the model significantly. ${ }^{13}$

The results are consistent, therefore, with the proposition that a significant transition effect accelerated trade union growth between 1946 and the early 1950s. Consistent with these findings, we will use equation 3.1 as a basis for extending our analysis of the determinants of Irish trade union growth in sections that follow.

\section{COMPETITIVENESS AND IRISH UNION GROWTH: THE 'SAPSFORD THESIS'}

We have argued that the significant negative price effect obtained by fitting the BainElsheikh model to Irish data is spurious. It is important, nonetheless, to consider explicitly an 
explanation for this unexpected result advanced by Sapsford $(1983 ; 1984)$ on the basis of his research into Irish trade union growth over the period 1944-77. Sapsford begins by noting the 'very pronounced tendency' for the Irish rate of price inflation to exceed that of the United Kingdom. This being the case, he argues, the resistance of Irish employers to unionization stiffens in periods of inflation due to concern that increased unionization will intensify 'wage push' and result in a deterioration in Ireland's competitiveness $v i s-\grave{a}$-vis its main trading partner (Sapsford, 1984; 311-312). An important implication of this argument is that $\Delta \mathrm{P}_{\mathrm{t}}$ is proxying trends in competitiveness in addition to-and to a greater degree than-the 'threat' and 'prosperity' effects postulated by Bain and Elsheikh. If this is so, and competitiveness relative to the UK could be measured more directly, then such an influence on Irish trade union growth might be confirmed. In that case, by allowing directly for such an effect, the remaining $\Delta \mathrm{P}_{\mathrm{t}}$ variable might indeed measure more reliably whether Irish trade union growth has been affected by 'threat' and 'prosperity' effects. The argument advanced by Sapsford-whether restricted to union growth during the period 1944-77-or extended to Irish trade union growth generally, as seems to be intendedappears to us unconvincing for economic and industrial relations reasons.

To begin with, during one of the periods of highest inflation experienced in the Irish economy, the early 1940s, little competitive disadvantage could have been suffered by Irish employers whatever the trend in Irish and British inflation rates. This was so, of course, simply due to the restriction-or, more precisely, atrophy - of trade resulting from wartime conditions. Relatedly, the tight regulation of wages during the same period would have dispelled any fears that a 'soft' stance on unionization might intensify wage push. Any fears of competitive disadvantage that might have arisen during the highly inflationary years from 1979 to 1983 , on the other hand, would also have been countervailed to some significant degree by the decline in the value of the punt against sterling following Ireland's accession to the EMS in $1979 .{ }^{14}$ Thus, during two of the inflationary peaks recorded between 1930 and 1984-the third spanned the period from 1973 to 1977-economic circumstances were such as to dampen any fears of competitive disadvantage that might have arisen due to the trend in Irish inflation relative to the United Kingdom. As regards the remaining 'peak' in the inflation trend, during the years after the first oil-shock, a rapid acceleration in prices occurred in both countries owing to their common dependence at that time on imported oil. ${ }^{15}$ Furthermore, until after 1966, when the Anglo-Irish Free Trade Agreement led to the dismantling of trade restrictions, trade between Ireland and the United Kingdom was heavily regulated by a system of tariffs and quotas. The existence of an extensive system of import quotas in Ireland had the effect of shielding Irish companies in the internationally traded goods sectors from the full rigours of competition with UK imports (Kennedy, 1971: 26-36; McAleese, 1971; McAleese and Martin, 1973). ${ }^{16}$

Questions of economics aside, there is no general evidence from research on Irish industrial relations that employers have in fact acted in accordance with such a view of the dangers attendant on the growth of unionization during periods of high inflation. While admittedly such an orientation might not be expected to come to light in any clear or coherent sense, it is often claimed that what has characterized Irish management-at any rate until recently-is, in fact, a pervasive failure to take account of competitiveness; and this can at least be supported by empirical evidence and general information on the conduct of Irish industrial relations over much of the period covered by our paper. ${ }^{17}$

Support for these theoretical propositions is obtained by introducing variables into the model to measure directly the effect of competitive disadvantage on the rate of union growth in Ireland. Consistent with Sapsford's own desiderata, these variables are derived from trends in Ireland's price level relative to the UK over the period from 1930 to $1984 .{ }^{18}$ As the share of total Irish trade accounted for by trade with the UK fell significantly over the period covered by this study, it might be expected that the overall significance of relative UK-Ireland inflation for competitiveness would also have 
declined. To take account of the declining share of UK trade in total Irish trade over this period, we thus 'trade weighted' the measures of competitive disadvantage. ${ }^{19}$ Finally, having pursued a regime of parity in currency values relative to sterling, from the foundation of the state to 1979 , Ireland broke with sterling after joining the European Monetary System in that year. As such, relative price trends have also been adjusted from 1979 to allow for the effect of exchange rate variations between the punt and sterling. While this modification might be considered to be of marginal significance, as it could only affect a small number of years, it has to be kept in mind that some of the largest-for Ireland, negative-divergences between Irish and British inflation rates occurred in the years between 1981 and 1983 .

The first measure of relative inflation we have used is the Irish (percentage) inflation rate minus the British, where years in which Irish inflation is lower than in Britain and years in which Irish deflation is higher are assigned a value of zero. (Clearly in these years Irish competitiveness was helped rather than endangered by relative price trends.) This variable $\left(\mathrm{C}_{\mathrm{t}}\right)$ was then weighted to allow for differences in the share of trade with the UK in total Irish trade to give a second variable, $\mathrm{C} 2{ }_{\mathrm{t}}$. This variable was in turn adjusted to allow for exchange rate variations since 1979 to give a third variable, $\mathrm{C} 3_{\mathrm{t}}$. Finally, three additional measures of relative price trends, $C 4_{t}, C 5_{t}$ and $C 6_{t}$ were also developed in the same way, but this time calculating the basic relative inflation variable, $\mathrm{C}_{\mathrm{t}}$, by subtracting absolute annual changes in the British consumer price index from changes in the Irish CPI. Again, also, years in which the trend in relative prices favoured Irish competitiveness were assigned a value of zero. ${ }^{20}$ The advantage of developing such a series of indicators is that it covers to a reasonable degree any objective pressures that might have arisen due to trends in relative inflation as well as any subjective attitudes that employers may have developed from observing relative price trends.

Whichever of these six competitiveness variables is introduced into the model, the results are similar: relative price trends have no significant effect on the rate of annual trade union growth. The coefficient on $\Delta \mathrm{P}_{\mathrm{t}}$ remains negative, of generally similar magnitude as in other equations, and insignificant. The results obtained when $\mathrm{C} 1_{t}, C 2_{t}$ and $C 3_{t}$ are used are presented, by way of example, in equations 3.2-3.4 of Table 3. Following the Sapsford hypothesis, the introduction of the $C$ variables should have overcome a specification error in the equations, thus improving the efficiency and consistency of the estimates.

On the basis of this evidence and the reasoning presented above, we therefore reject the hypothesis that trends in Irish inflation relative to the UK have exerted a significant effect on Irish trade union growth.

\section{CYCLICAL EFFECTS ON OPPORTUNITY AND PROPENSITY TO UNIONIZE}

Must we conclude from the analysis presented thus far, in particular from the insignificance of the price term in models which contain a potential membership term and a competitiveness term, that no reasonably consistent 'threat effect' operates on the rate of union growth in Ireland? It could still be countered that a threat effect operates on employees' propensity to unionize but that the coefficient of the usual measure of the threat effect, the $\Delta P_{t}$ term, is conflated by countervailing trends in labour market slackness-even when we attempt to neutralize the effect of such countervailing pressures on the price term by introducing $\Delta \mathrm{E}_{\mathrm{t}}$.

One means of further investigating the possibility that a threat effect exists but is neutralized in the regressions due to measurement difficulties is to introduce separate inflationary and stagflationary price trend variables into the equation. This is done by defining a price inflation variable $\left(\Delta \mathrm{PG}_{t}\right)$ which takes on observed annual values for years in which the level of unemployment is less than the mean or median for Ireland over the period 1932-84 and which is assigned the value of zero for years when unemployment equals or exceeds these 'norms'. ${ }^{21}$ Clearly, this variable will measure any threat effects in years of relatively low unemployment. A second variable is then defined $\left(\Delta \mathrm{PS}_{\mathrm{t}}\right)$ to measure the effects of price rises in periods of 
stagflation. This variable takes on normal annual values when the level of unemployment is greater than, or equal to, the mean or median levels of unemployment over the period studied and is otherwise assigned a value of zero.

If a threat effect is operating on propensity to unionize, arguably it should be apparent in periods of prosperity when the conflating influence of stagnation on the price trend variable is not present.

The results obtained when these variables are introduced into the model-using the mean unemployment rate to distinguish between inflationary and stagflationary conditions between 1932-84-are presented in equations 3.4 and 3.5 of Table $3 .{ }^{22}$ These results are of considerable interest and suggest that the Bain-Elsheikh proposition regarding the effects on union growth of $\Delta \mathrm{P}_{\mathrm{t}}$ appears invalid in the Irish situation, irrespective of the state of the labour market. The findings show no indication of a threat effect at low unemployment but point to a weak and insignificant negative price effect in periods of relatively low and relatively high unemployment. ${ }^{23}$

This leaves us with the problem of explaining why the rate of price inflation appears to have had no significant effect on the rate of trade union growth in Ireland, when we control for variations in labour market slackness otherwise proxied by $\Delta \mathrm{P}_{\mathrm{t}}$. The most plausible explanation is that the threat effect was institutionally neutralized or weakened in the Irish case. This may have arisen owing to the prominence, or even dominance, of changes in the cost of living in the wage policies of Irish trade unions, and (since 1946) in the dynamics of wage rounds. During the 1970s a series of national wage agreements strengthened the influence of the CPI on wage adjustment by introducing cost of living escalator clauses to protect the real value of wage rises in the face of sharply escalating inflation (see O'Brien, 1981). This latter development meant that for a significant part of the period with which we are concerned a high level of nearly automatic protection against inflation was provided for the majority of employees, whether unionized or not, through the operation of the wage bargaining system. ${ }^{24}$

If basic pay levels across a wide range of industries were thus protected against inflation, and if this in turn became a firm expectation among employees, the institutional features of pay determination may have reduced the perceived threat posed by rising prices for employees' standard of living. In other words, employees may have become accustomed to the expectation that wage levels would respond to changes in price levels, with a concomitant reduction in the 'threat effect' postulated by Bain and Elsheikh. ${ }^{25}$

In the same way that the existence of a consistent threat effect must be doubted in the Irish case, so too must Bain and Elsheikh's postulated tendency for employers' propensity to resist unionization and employees' confidence in embracing it, to vary directly with the business cycle. The positive coefficient on $\Delta \mathrm{E}_{\mathrm{t}}$ may simply indicate that the annual rate of unionization varies in response to variations in opportunity to unionize, as determined by the size of the employed work-force. Stronger evidence is needed if we are to be able to conclude with any confidence that employees' and employers' propensities or attitudinal dispositions towards unionization vary in the manner hypothesized. On the face of it, this evidence cannot be found in the Irish case.

To begin with, if propensities regarding unionization varied in the manner outlined by Bain and Elsheikh, we might expect the coefficient on $\Delta \mathrm{E}_{\mathrm{t}}$ to be greater than unity: that is, we might expect the rate of union growth to recover more sharply than the rate of employment growth in the upswing of the cycle and the opposite to occur in the downswing. But irrespective of how union growth equations are specified, $\Delta \mathrm{E}_{\mathrm{t}}$ consistently remains below unity.

Further negative results are obtained when we introduce a profits term into the equation in an attempt to provide a more sensitive measure of variations in business buoyancy. ${ }^{26}$ Sapsford found that the level of real profits had a significant effect on union growth in Ireland in the period 1943-77 and this finding was underscored by Smyth's analysis of Irish union growth over the period 1946-77 (Sapsford, 1984: 314-315; Smyth, 1985: 200-201). ${ }^{27}$ The results obtained when variables measuring the annual rate of change in money profits $(\Delta \mathrm{II})_{t}$ and real profits 
$\Delta(\mathrm{II} / \mathrm{P})_{\mathrm{t}}$ are introduced into a model estimated over the period 1943-84-the period for which Sapsford reports positive findings-are presented in equations 6.1 and 6.2 of Table 6 below. Neither variable attains significance and the coefficients on other terms of the model are virtually unaffected by their inclusion. ${ }^{28}$ Again the evidence is against viewing variations in business buoyancy as a source of changes in propensities with respect to unionizationeither in the case of employees or employers.

\section{LABOUR MARKET INTERDEPENDENCE AND UNION GROWTH: THE 'SMYTH THESIS'}

This study has established that annual variations in employment, that is, in net job gains or losses, significantly influence the rate of trade union growth but that the annual level of unemployment has no effect.

Using Sapsford's data, Smyth (1985) concluded that there was evidence that the annual rate of union growth in the Irish Republic over the period 1946-77 was affected by the level of unemployment in Ireland relative to the UK. Smyth finds little surprise in this on theoretical grounds and notes that the Irish and UK labour markets are interdependent in significant respects and that numerous studies have shown that the relative unemployment rates in Ireland and the United Kingdom are important in determining the flow of Irish workers to, and back from, the United Kingdom. Smyth hypothesizes that the higher the Irish unemployment rate relative to that of the UK (UI-UK ${ }_{t}$ ), the higher will be the level of migration out of the Irish work-force and the greater the drag exerted on Irish union growth.

One obvious reason why the level of, or rate of change in, unemployment per se is found to have no significant effect on the rate of trade union growth in Ireland may be that measured unemployment is a poor indicator of labour market slackness due to migration flows. Looked at in this sense, Smyth's variable, $\mathrm{UI}-\mathrm{UK}_{\mathrm{t}}$, can be seen to represent a measure of the level of unemployment in Ireland adjusted for the 'migratory pull' exerted by UK economic conditions. Irrespective of whether the con- strained migration flows of the War years are included or excluded, our results indicate that UI- $\mathrm{UK}_{t}$ has no significant effect on the rate of trade union growth in a model estimated over the period beginning in 1932 - the first year for which a value of this variable can be derived (equations 4.1 and 4.2 of Table 4$){ }^{29}$ Nor does UI-UK $\mathrm{t}_{\mathrm{t}}$ attain significance when added to our preferred model estimated over the period 1946-77. Negative results are also obtained when $\mathrm{UI}-\mathrm{UK}_{\mathrm{t}}$ is replaced by a variable measuring migration flows directly $\left(\mathrm{MIG}_{\mathrm{t}}\right)$ (equations 4.3 and 4.4) ${ }^{30}$ It must be concluded, therefore, that Smyth's results, like those of Sapsford, are the outcome of poor data and a mis-specified model. $^{31}$

Given the failure of measures of migration to account for the absence of a significant relationship between unemployment and the rate of union growth, it is important to consider alternative possibilities. An examination of a scatterplot of unemployment and the rate of union growth indicated clearly that the result could not be accounted for by 'outliers' or exceptional annual values. Nor are any nonlinear patterns apparent that would suggest a more complex relationship between the variables than the simple linear and concurrent relationship posited in the Bain-Elsheikh model. The first problem that arises is that even if we attempt, as above, to correct for migration flow into and out of the Irish work-force by introducing an explicit migration term, the migration data-notoriously problematic in the Irish case-include (variable) numbers of spouses and dependants of working migrants. Second, variations in labour market buoyancy are known to have a strong pro-cyclical effect on numbers entering the live register: a rise in the demand for labour has tended, at least in some periods, to raise the supply at a higher rate than unemployment has declined. So in the Irish case employment can increase in any year without a corresponding fall in unemployment. These factors indicate that the measured rate of unemployment in Ireland is a poor indicator of variations in opportunity to unionize. However, there is also a reason for suggesting that it is also a poor indicator of variations in propensity to unionize. Bain and Elsheikh (1976: 65-66) sug- 
TABLE 4 Trade union growth in Ireland, 1930-1984: real wages, relative unemployment and migration effects

\begin{tabular}{|c|c|c|c|c|}
\hline Equation & 4.1 & 4.2 & 4.3 & 4.4 \\
\hline Period & $1932-84$ & $1932-84^{(a)}$ & $1930-84$ & $1930-84^{(a)}$ \\
\hline Method & OLS & OLS & OLS & OLS \\
\hline $\mathrm{R}^{2}$ & $0.8342^{*}$ & $0.7892 *$ & $0.7901 *$ & $0 \cdot 7202^{*}$ \\
\hline $\mathrm{F}$ & $32 \cdot 3485$ & 24.9533 & $25 \cdot 2275$ & $18 \cdot 0147$ \\
\hline DW & $2 \cdot 21 \dagger$ & $2 \cdot 12 \dagger$ & $1.91 \dagger$ & $1 \cdot 85 \dagger$ \\
\hline Constant & $\begin{array}{l}7 \cdot 0795^{*} \\
(6 \cdot 057)\end{array}$ & $\begin{array}{l}6 \cdot 5688^{*} \\
(4 \cdot 364)\end{array}$ & $\begin{array}{l}5 \cdot 8287^{*} \\
(4 \cdot 766)\end{array}$ & $\begin{array}{l}4 \cdot 7428^{*} \\
(3 \cdot 164)\end{array}$ \\
\hline$\Delta W_{t}$ & $\begin{array}{l}0 \cdot 3000^{*} \\
(3 \cdot 142)\end{array}$ & $\begin{array}{c}0.2195 * \\
(2 \cdot 354)\end{array}$ & $\begin{array}{l}0 \cdot 3065^{*} \\
(2 \cdot 767)\end{array}$ & $\begin{array}{c}0 \cdot 2475 \\
(2 \cdot 180)\end{array}$ \\
\hline $\mathrm{DE}_{\mathrm{t}-1}$ & $\begin{array}{l}-0.1597 * \\
(-4 \cdot 777)\end{array}$ & $\begin{array}{l}-0 \cdot 1465^{*} \\
(-3 \cdot 360)\end{array}$ & $\begin{array}{l}-0 \cdot 1463 * \\
(-4 \cdot 071)\end{array}$ & $\begin{array}{l}-0.1202^{*} \\
(-2.292)\end{array}$ \\
\hline$\Delta \mathrm{E}_{\mathrm{t}}$ & $\begin{array}{l}0 \cdot 8510^{*} \\
(5 \cdot 762)\end{array}$ & $\begin{array}{l}1 \cdot 0481^{*} \\
(5 \cdot 869)\end{array}$ & $\begin{array}{l}0 \cdot 8471^{*} \\
(5 \cdot 487)\end{array}$ & $\begin{array}{c}1 \cdot 0019 * \\
(5 \cdot 260)\end{array}$ \\
\hline$\Delta \mathrm{P}_{\mathrm{t}}$ & $\begin{array}{r}-0 \cdot 1555 \\
(-1 \cdot 873)\end{array}$ & $\begin{array}{c}-0 \cdot 1131 \\
(-1 \cdot 228)\end{array}$ & $\begin{array}{c}-0.0990 \\
(-1 \cdot 125)\end{array}$ & $\begin{array}{c}-0.0852 \\
(-0 \cdot 838)\end{array}$ \\
\hline $\mathrm{WS}_{\mathrm{t}}$ & $\begin{array}{l}-15 \cdot 8698^{*} \\
(-7 \cdot 014)\end{array}$ & & $\begin{array}{l}-15 \cdot 4464^{*} \\
(-6 \cdot 124)\end{array}$ & \\
\hline $\mathrm{T}$ & $\begin{array}{l}3 \cdot 7710^{*} \\
(3 \cdot 923)\end{array}$ & $\begin{array}{c}3 \cdot 7103^{*} \\
(3 \cdot 677)\end{array}$ & $\begin{array}{c}4.2276^{*} \\
(4 \cdot 073)\end{array}$ & $\begin{array}{l}4 \cdot 3669^{*} \\
(4 \cdot 224)\end{array}$ \\
\hline UI-UK $_{\mathrm{t}}$ & $\begin{array}{r}0.0773 \\
(0 \cdot 878)\end{array}$ & $\begin{array}{l}0 \cdot 12439 \\
(1 \cdot 127)\end{array}$ & & \\
\hline $\mathrm{MIG}_{\mathrm{t}}$ & & & $\begin{array}{r}0.0243 \\
(0 \cdot 871)\end{array}$ & $\begin{array}{c}0.0281 \\
(1.045)\end{array}$ \\
\hline
\end{tabular}

Note: (a) Excluding 1939-45.

gested that the rate of unemployment coloured employees' disposition towards unionization; in times of high unemployment people were deterred from joining unions by fear of employer hostility and a sense of general union ineffectiveness. The Irish rate of unemployment probably had little subjective effect on employees. Table 5 presents data on the average levels and variability of unemployment in the nations studied by Bain and Elsheikh and in Ireland. The measures of central tendency and variability are calculated over the periods covered by Bain and Elsheikh's regressions and over the period 1932-84 in the case of Ireland. The most salient feature of the data is the fact that both mean and median levels of unemployment in Ireland are significantly higher than in any other country, while the variability of unemployment is lower. Given that Ireland is characterized by relatively high average unemployment and low unemploy- ment variability, it seems reasonable to suggest that employees and employers may have become somewhat inured to prevailing rates of unemployment, with a concomitant decline in the deterrence effect of unemployment implied by Bain and Elsheikh. In short, part of the influence unemployment might be expected to exert on the rate of union growth may have been neutralized in the Irish situation owing to an 'inurement effect' arising out of the peculiarities of Ireland's unemployment problem.

\section{THE NEUTRAL EFFECT OF BARGAINING STRUCTURE, POLITICS AND INDUSTRIAL CONFLICT}

The institutional character of wage bargaining The system of wage bargaining in Ireland since the Second World War has been characterized by a well-developed pattern of inclusive wage 
TABLE 5 The level and variability of unemployment in Ireland and in nations studied by Bain and Elsheikh ${ }^{(a)}$

\begin{tabular}{|c|c|c|c|c|c|}
\hline & Period & Mean & Median & $\begin{array}{l}\text { Standard } \\
\text { deviation }\end{array}$ & Variance \\
\hline Ireland & 1932-1984 & $9 \cdot 7$ & $8 \cdot 8$ & $3 \cdot 6$ & $12 \cdot 9$ \\
\hline United Kingdom & $1882-1970$ & $5 \cdot 6$ & $3 \cdot 1$ & $5 \cdot 3$ & $28 \cdot 5$ \\
\hline United States & $1897-1970$ & $6 \cdot 9$ & $5 \cdot 0$ & $5 \cdot 5$ & $30 \cdot 7$ \\
\hline Australia & 1907-1969 & $4 \cdot 7$ & $3 \cdot 4$ & $4 \cdot 3$ & $18 \cdot 4$ \\
\hline Sweden & $1914-1970$ & $7 \cdot 2$ & $4 \cdot 6$ & $6 \cdot 5$ & $42 \cdot 1$ \\
\hline
\end{tabular}

Sources: Data in Bain and Elsheikh (1976) Appendix E; Irish sources outlined in Appendix 1.

Note: (a) Measures of central tendency and variability are calculated in the table for the periods over which union growth models have been estimated.

rounds. In periods when rounds were under way the bargaining activity of unions in different sectors of the labour market was highly synchronized. Given the institutional importance of the round system in Irish wage bargaining, it seems worthwhile to test whether the incidence of rounds per se may have exerted an influence on trade union growth, irrespective of the levels of pay increases unions were negotiating.

Several dummy variables were used to test for a distinct institutional wage round effect on Irish trade union growth (for details see Roche and Larragy, 1989: 44). The results suggested that the wage round system exerted no distinct institutional effect on union growth, separable from the effect of wage rises. When a simple wage round dummy $R$ is introduced into a model which includes a wage term (equation 6.3 of Table 6), neither term attains significance at the chosen level. Of some interest, however, are the results obtained when $R$ is substituted for the wage term (equation 6.4). The dummy just fails to attain significance at the 99 per cent level, though it is significant at the 95 per cent level; but its standardized regression coefficient (beta) at 0.31 is not much smaller than the standardized coefficients obtained on the wage term in different models. ${ }^{32}$ This suggests that the magnitude of the wage rises achieved in rounds are not a great deal more consistent or important than the simple occurrence of rounds in their effect on trade union growth. In other words, the fact that a round occurred was almost as significant as the magnitude of the wage rises achieved in the round. This points to the occurrence in Ireland of a more generalized and more institutionally rooted 'credit effect' of wage rises on union growth than that originally postulated by Bain and Elsheikh.

\section{The level of wage bargaining}

As indicated above, wage rounds since the War occurred through collective bargaining at a decentralized level and at national level. An argument could be advanced why national wage agreements might be expected to have exerted a drag on union membership. National pay agreements, if strictly adhered to by unions, seem likely to intensify the 'free rider problem' which they inevitably face in delivering 'public goods' such as wage rises or improvements in social and economic policy. In periods when national wage agreements are in operation, pay bargaining may be taken out of the hands of officials at local level, with a consequent reduction in union and peer pressure on employees to join, or remain in, unions. As a result, union recruitment may suffer in spite of the greater national prominence that unions might otherwise enjoy. ${ }^{33}$ If on the other hand, there is extensive evasion of national norms through supplementary bargaining and wage drift at lower levels of bargaining, the free rider problem may be countervailed and neutralized and the existence of a national wage bargaining system may have a negligible effect on union growth. While few data are available on the extent of supplementary bargaining under Irish national wage agreements, there are 
TABLE 6 Trade union growth in Ireland, 1930-1984: Profits and the institutional character of wage bargaining

\begin{tabular}{|c|c|c|c|c|}
\hline Equation & 6.1 & 6.2 & 6.3 & 6.4 \\
\hline Period & $1943-84$ & $1943-84$ & $1930-84$ & $1930-84$ \\
\hline Method & OLS & OLS & OLS & OLS \\
\hline $\mathbf{R}^{2}$ & $0 \cdot 8017^{*}$ & $0 \cdot 8025^{*}$ & $0.7966^{*}$ & $0.7806^{*}$ \\
\hline $\mathrm{F}$ & $23 \cdot 5800$ & $23 \cdot 7032$ & $26 \cdot 2839$ & 28.4599 \\
\hline DW & $2 \cdot 22 \dagger$ & $2 \cdot 22 \dagger$ & $1.91 \dagger$ & $1.91 \dagger$ \\
\hline Constant & $\begin{array}{l}9 \cdot 3245^{*} \\
(4 \cdot 669)\end{array}$ & $\begin{array}{c}9 \cdot 3686^{*} \\
(4 \cdot 715)\end{array}$ & $\begin{array}{c}6 \cdot 9676^{*} \\
(5 \cdot 300)\end{array}$ & $\begin{array}{c}6 \cdot 5049 * \\
(4 \cdot 898)\end{array}$ \\
\hline$\Delta \mathrm{W}_{\mathrm{t}}$ & $\begin{array}{r}0 \cdot 2451 \\
(0 \cdot 823)\end{array}$ & $\begin{array}{c}0 \cdot 2436 * \\
(2 \cdot 480)\end{array}$ & $\begin{array}{l}0 \cdot 2105^{*} \\
(2 \cdot 473)\end{array}$ & \\
\hline $\mathrm{DE}_{\mathrm{t}-1}$ & $\begin{array}{l}-0 \cdot 1954^{*} \\
(-4 \cdot 340)\end{array}$ & $\begin{array}{l}-0 \cdot 1970^{*} \\
(-4 \cdot 383)\end{array}$ & $\begin{array}{l}-0 \cdot 1825^{*} \\
(-4 \cdot 020)\end{array}$ & $\begin{array}{l}-0 \cdot 1674^{*} \\
(-3 \cdot 644)\end{array}$ \\
\hline$\Delta \mathrm{E}_{\mathrm{t}}$ & $\begin{array}{l}0.74322^{*} \\
(4 \cdot 571)\end{array}$ & $\begin{array}{c}0.7377^{*} \\
(4 \cdot 529)\end{array}$ & $\begin{array}{c}0 \cdot 8928^{*} \\
(5 \cdot 710)\end{array}$ & $\begin{array}{c}1 \cdot 0384^{*} \\
(7 \cdot 390)\end{array}$ \\
\hline$\Delta P_{t}$ & $\begin{array}{c}-0 \cdot 1000 \\
(-1 \cdot 059)\end{array}$ & $\begin{array}{l}-0.0712 \\
(-0.687)\end{array}$ & $\begin{array}{l}-0.0478 \\
(-0.515)\end{array}$ & $\begin{array}{c}0 \cdot 0803 \\
(1 \cdot 213)\end{array}$ \\
\hline $\mathrm{WS}_{\mathrm{t}}$ & & & $\begin{array}{l}-15 \cdot 6834^{*} \\
(-6 \cdot 358)\end{array}$ & $\begin{array}{l}-16 \cdot 2550^{*} \\
(-6 \cdot 461)\end{array}$ \\
\hline $\mathrm{T}$ & $\begin{array}{l}3 \cdot 5245^{*} \\
(3 \cdot 648)\end{array}$ & $\begin{array}{c}3 \cdot 5222 * \\
(3 \cdot 654)\end{array}$ & $\begin{array}{c}3 \cdot 3397^{*} \\
(2 \cdot 696)\end{array}$ & $\begin{array}{l}3 \cdot 2242^{*} \\
(2 \cdot 536)\end{array}$ \\
\hline$\Delta \mathrm{II}_{\mathrm{t}}$ & $\begin{array}{c}0 \cdot 0238 \\
(0 \cdot 823)\end{array}$ & & & \\
\hline$\Delta(\mathrm{II} / \mathrm{P})_{\mathrm{t}}$ & & $\begin{array}{c}0.0291 \\
(0.910)\end{array}$ & & \\
\hline $\mathrm{R}$ & & & $\begin{array}{c}2 \cdot 0875 \\
(1 \cdot 504)\end{array}$ & $\begin{array}{c}3 \cdot 0783 \\
(2 \cdot 325)\end{array}$ \\
\hline
\end{tabular}

indications that it was extensive-at any rate, under the 1970 s 'generation' of national wage deals. ${ }^{34}$

Conceptual problems arise in testing for a bargaining structure effect on Irish trade union growth and these are outlined elsewhere (Roche and Larragy, 1989: 47). Several dummies were tried but all results were negative. Equation 7.1 of Table 7 presents the results obtained when a dummy (Nat) is included which covers all national agreements since 1945 . The coefficient on Nat is negative but statistically insignificant. ${ }^{35}$ It can be concluded then that the level at which pay bargaining formally occurred in Ireland has had a negligible influence on trade union growth. This can be attributed to the fact that national deals in the period up to 1970 often did little more than set down a broad framework for local negotiations, and that in the period 197081 there was extensive evasion of national wage norms.

\section{The political composition of government}

Several studies of trade union growth have investigated whether the political composition of parliaments or governments has affected trade union growth (Ashenfelter and Pencavel, 1969; Schnabel, 1987; Armingeon, 1988; Carruth and Disney, 1988). The degree to which the complexion of government influences union growth will depend for the most part on the character of the political cleavages that distinguish the party systems of different nations. This being so, there are good reasons to expect 
TABLE 7 Trade union growth in Ireland, 1930-1984: The level of wage bargaining, political composition of government and workers involved in strike activity

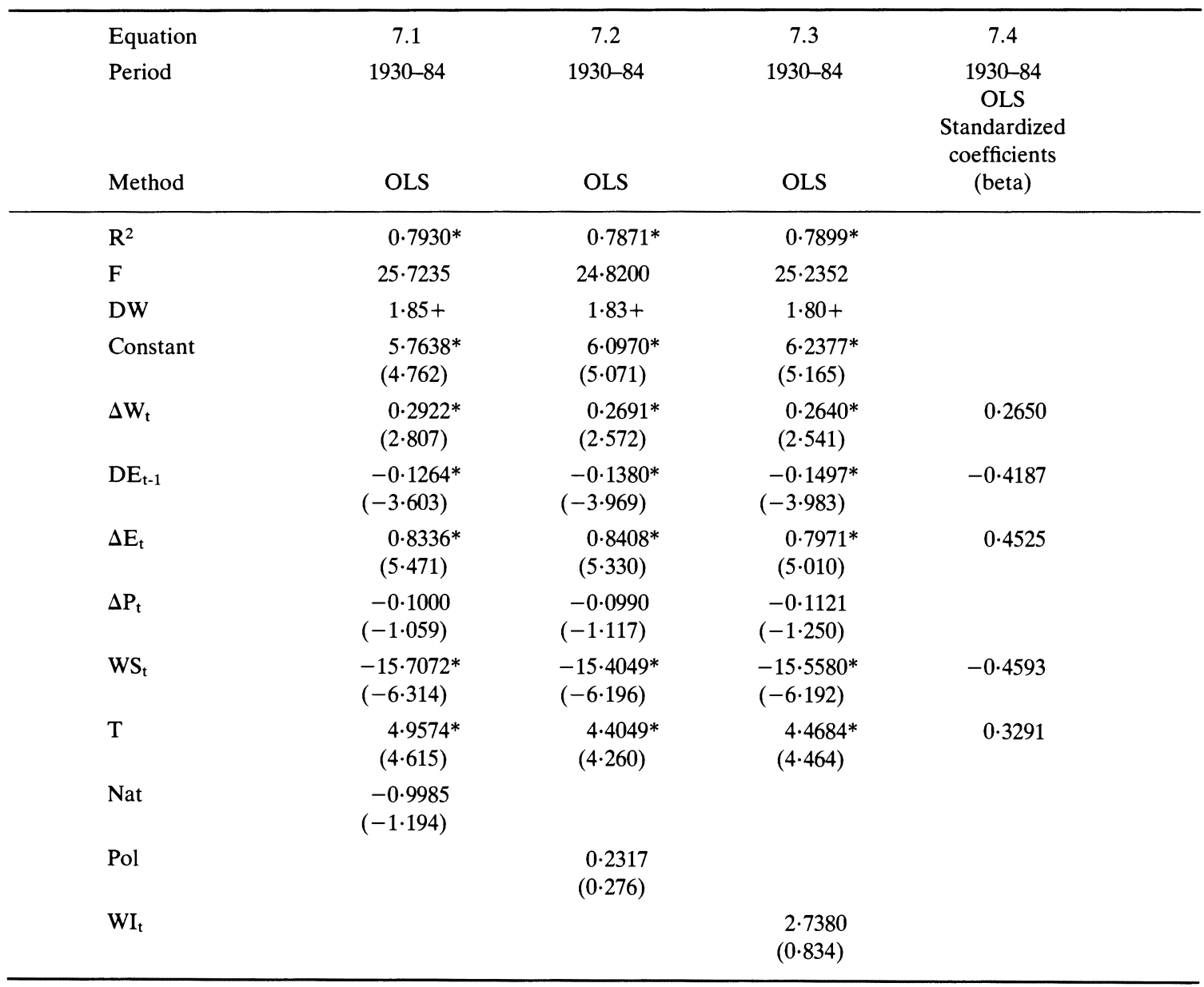

that the composition of Irish governments will have no significant effect on unionization. For what has characterized the politics of industrial relations in Ireland is the absence of any significant divergence in the policies of the major political parties on unions and collective bargaining. It is possible to identify differences of emphasis and priority, but industrial relations issues have not been politicized by the major parties to the degree that has obtained in party systems where the main cleavage has developed around 'class politics'. While a case could be made that the Irish Labour Party has followed a distinct and class-focused policy on industrial relations matters, the fact that Labour has entered government only as a minor coalition partner has meant that in practice it has had to operate within, or in tension with, lines of policy pursued by one of the major parties. Two 'political effect' dummies were tested in our preferred model. The first was assigned a value of unity for years in which the Labour Party participated in coalition governments and in the case of the year 1932 when Labour supported a minority Fianna Fail government; the second was assigned a value of unity for years in which these governments had been in power for more than six months. The results were similar in both 
cases: there is no evidence of a party-political influence on trade union growth and decline in Ireland. The results on the first dummy (Pol) are presented in equation 7.2; the sign on Pol is positive but the coefficient is very insignificant.

\section{Strike activity}

Union membership might be expected to rise during strike waves for several reasons. First, high levels of strike activity may reflect extensive worker dissatisfaction with a complex of industrial relations issues and growing assertiveness or militancy, which may find expression in higher levels of unionization. Second, strike waves may on balance foster attachment to unions through their often observed effect on building solidarity and through their concurrence with union campaigns and pressure at workplace level. Finally, it has been suggested that increasing industrial conflict may induce employees to join unions in order to receive strike pay. It has to be recognized, on the other hand, that increased strike activity may not always act as a stimulus to union growth. Large and/or prolonged strikes that collapse in defeat for unions have been known to lead to serious membership losses. Such strikes are the exception rather than the rule, however, as in most instances of strike action no clear 'winner' is evident and the other concomitants of strike action probably work to the advantage of unions. It might be hypothesized then the level of strike activity will be positively related to union growth.

It is still open whether workers involved or working days lost represents the best indicator of the level of strike activity as it affects trade union growth. The number of workers involved in strikes each year seems preferable in that it measures the annual incidence of worker experience of strike activity. Working days lost should nonetheless be examined as well in that it is a more parsimonious indicator of the overall volume of strike activity. Irrespective of the indicator used (equation 7.3 presents the results when worker involvement, $\mathrm{WI}_{t}$, is introduced into the model), the results fail to confirm the hypothesis and strike activity is revealed as having no significant effect on Irish trade union growth.

\section{CONCLUSION}

This paper has presented a detailed examination of the cyclical and institutional determinants of annual trade union growth and decline in Ireland. The paper has tried to account for some of the puzzling and negative results obtained when the Bain-Elsheikh and other business cycle models are fitted to Irish data. It emerges that the 'peculiarities' of the Irish labour market and of the institutional structure of Irish industrial relations present a severe test to models developed to address the more orthodox labour markets of more developed industrial nations. In politics, too, Ireland is distinctive: the absence of a major cleavage in the manner in which the main parties have approached the politics of industrial relations means that no significant political influence on trade union growth has been apparent since 1930 .

The alternative model of Irish trade union growth developed in this paper is estimated finally with all insignificant variables excluded in equation 7.4 of Table 7 . The model can be summarized as follows:

$$
\begin{gathered}
\Delta \mathrm{M}_{\mathrm{t}}=\beta_{0}+\beta_{1} \Delta \mathrm{W}_{\mathrm{t}}+\beta_{2} \mathrm{WS}_{\mathrm{t}}+\beta_{3} \Delta \mathrm{E}_{\mathrm{t}}+\beta_{4} \mathrm{~T}+ \\
\beta_{5} \mathrm{DE}_{\mathrm{t}-1}+\epsilon_{\mathrm{t}}
\end{gathered}
$$

Where $\Delta \mathrm{W}_{\mathrm{t}}=$ the rate of change in earnings; $\mathrm{WS}_{\mathrm{t}}$ is a dummy variable included to take account of the introduction of a wages standstill in $1941(1941=1$, all other years $=0) ; \Delta \mathrm{E}_{\mathrm{t}}=$ the rate of change in civilian employees at work; $\mathrm{T}=\mathrm{a}$ dummy variable included to allow for a post-war 'transition effect' on union growth $(1946-52=1$, all other years $=0) ; \mathrm{DE}_{\mathrm{t}-1}=$ the level of employment density lagged one year $+\epsilon_{t}$ is a random error term.

In this model the expected signs on the coefficients are:

$$
\beta_{1}, \beta_{3}, \beta_{4}>0 \text { and } \beta_{2}, \beta_{5}<0 \text {. }
$$

\section{NOTES}

1. It is postulated that the rate of change in unemployment, $\Delta U_{t}$ may also affect growth even if no significant effect is exerted by the level of unemployment $U_{t}$. It is also thought possible that $U_{t}$ and $\Delta P_{t}$ may operate oneor two-year lags. The possibility of a non-linear effect in the case of union density is also considered, as is the possibility that the effect of prices on union growth may 
be moderated at higher levels of inflation (Bain and Elsheikh, 1976: 68-71).

2. Autocorrelated residuals render tests of significance unreliable and can affect parameter estimates and $R^{2} \mathbf{s}$. The problem of autocorrelation in time series and the Cochrane-Orcutt procedure are discussed in Ostrom (1978: 20-41).

3. The usual tests indicate that this finding cannot be accounted for by multicollinearity between wages and prices, though the zero-order correlation between these variables is nevertheless high, $r=0 \cdot 72$. (On the problem of multicollinearity, see Lewis-Beck, 1980: 58-63.)

4. In all the countries examined by Bain and Elsheikh, zero-order correlations between the rate of price inflation and the level of unemployment are negative. In the Irish case, however, a positive coefficient $(r=0.225)$ is obtained.

5. As we saw, Bain and Elsheikh seek to allow for the impact on union membership of changes in 'potential membership' by means of a lagged density term $\left(D_{t-1}\right)$. In deciding against the inclusion of an explicit potential membership term, Bain and Elsheikh departed from the practice adopted in earlier econometric research (Ashenfelter and Pencavel, 1969; Sharpe, 1971). Their primary reason for omitting a term allowing directly for the impact on union growth of variations in potential union membership seems to have been that their British labour force data before 1948 were derived by means of linear interpolation of decennial Census of Population data, with the result that a variable constructed from them would exhibit little year-to-year variation (Bain and Elsheikh, 1976: 67-68). In the Irish case we were able to derive a more reliable indicator of annual changes in the employee work-force than could be obtained by linear interpolation (see Appendix 1). Bain and Elsheikh (1976: 37-39) also underscore Mancke's well-known criticism of Ashenfelter and Pencavel's use of potential membership as a regressor.

In essence the argument is that the coefficient on such a term can be of little interest in that it is almost definitional that a change in potential membership, ceteris paribus, will lead to an equal proportional change in union membership. This argument, however, should not be accepted uncritically, particularly in the Irish case. First of all, as has been argued, the omission of such a term might result in other terms proxying effects other than those they were included to measure, leading to biassed coefficients and spurious results. Second, the coefficient on the potential membership term might range from below to above unity-the coefficient implied by Mancke's criticism-producing interpretable and possibly important results.

Finally, where we have reason to believe that the measured rate of unemployment is a poor indicator of labour market slackness, a potential membership term might be expected to pick up more directly the postulated effect of variations in the labour market on union growth.

6. The possibility of non-linear relationships between density and the rate of union growth was examined in detail. On theoretical grounds and following earlier research, we tested inverse and quadratic functional forms of the density variable (see Roche and Larragy, 1989: 56-57). The results suggested that the linear form reported here was preferable.

7. An F test conducted on model 2.2 when one additional case (1932) was added confirmed that it was unstable (in effect, due to the instability of $\left.\Delta \mathrm{P}_{\mathrm{t}}\right)$. The calculated $\mathrm{F}$ ratio was $8 \cdot 0$, compared with a theoretical $F$ at the 99 per cent level of 3.07. A further test conducted on the same model, but excluding the insignificant $U_{t}$ term, when three additional cases were added (1930-32) also pointed to instability: giving a calculated $F$ of $5 \cdot 5$, compared with a theoretical F of 3.22. (For details of the usages of F tests, see Kamenta, 1971.)

8. A plot of the standardized residuals of equation 2.3 of Table 2 reveals that during these years the model on average mispredicts (in fact, by over-predicting) the rate of trade union growth by a greater degree than during any other period.

9. The use of $\Delta W F_{t}$ as a measure of changes in potential membership will not have the same effect on the explanatory significance of the price term because it cannot track variations in labour market slackness as directly as $\Delta \mathrm{E}_{\mathrm{t}}$.

10. The strong emphasis of union wage policy on the restoration of pre-war living standards is outlined in O'Mahony (1965).

11. While this is clearly inconvenient for econometric methodology, it seems to us to call into question Bain and Elsheikh's dismissal (op. cit., pp. 11-25) of attempts to allow for economic and social convolution in theories of trade union growth. It is worth noting in this regard that the nations to which the theory was applied in Union Growth and the Business Cycle, Britain, the USA, Australia and Sweden, are all countries characterized by relatively stable economic and social development during the late nineteenth and twentieth centuries.

12. It should be noted that when 1951 or 1950 are used as termination years, $\Delta \mathrm{W}_{\mathrm{t}}$ fails to attain significance at the 95 per cent level.

13. The calculated $\mathbf{F}$ ratio obtained from a comparison of equations 2.4 and 3.1 is 64.9 , and this greatly exceeds the theoretical $F$ value of $7 \cdot 19$ at the 99 per cent level of probability. It can be suggested that the three factors we believe to have given rise to a transition effect followed, so to speak, different 'trajectories of decay'. This renders it difficult to select a formal decay function that might best model the attenuation of the transition effect. (For a discussion of this issue, see Roche and Larragy, 1989: 24.)

14. Indeed, the competitiveness of Irish exports on the UK market increased sharply during this period (see Conniffe and Kennedy, 1984: Ch. 6).

15. In both countries the 1977 retail price index was just under double its pre-oil crisis 1973 level.

16. McAleese and Martin (1973: 45) draw attention to the 'exceedingly high' effective tariff protection enjoyed by Irish manufacturers. While the greater part of Irish import trade with the UK consisted of trade in manufactured goods and raw materials, the major proportion of 
Irish exports to the UK since the foundation of the State was accounted for by trade in livestock and food. (See Kennedy, 1971: 31-32.)

17. Research evidence concerning the unresponsiveness of Irish management to labour practices over the greater part of the period which concerns us can be found in the studies of 22 industries conducted during the 1960s by the Committee on Industrial Organization (CIO). As well as identifying a general lack of concern for competitiveness in Irish business, the CIO (Industry Reports, various years; 1965 ) repeatedly drew attention to what it saw as management acquiescence in 'seriously inefficient' labour practices. See also the 1960s Irish Management Institute survey of management (Tomlin, 1966).

18. Sapsford (1984: 313) points out that he experimented with measures of competitiveness in his regressions covering the period $1943-77$, and that the results suggested that relative price trends had a significant influence on union growth.

19. From 1932 to 1984 the UK share of total Irish trade fell from over 80 per cent to just under 40 per cent. Regrettably, there is no consistent means of identifying the changing UK share of Irish trade in manufactured goods over this period.

20. While the ratio of Irish to British inflation-measured as a ratio of absolute annual changes in index points or in proportionate terms-might seem the simplest measure of relative price trends, it has the disadvantage that for years when either Irish or British prices remained unchanged, it is not possible to calculate values.

21. The mean Irish unemployment rate over this period was 10 per cent, and the median rate was 8.9 per cent.

22. Given that the mean and median unemployment rates are practically the same, the results are similar regardless of which measure is used to distinguish between inflationary and stagflationary price rises. Similar results are obtained when the mean and median of $\Delta E_{t}(1930-84)$ are used to define inflationary and stagflationary price terms.

23. Following Bain and Elsheikh, we tested for the possibility that inflation might be related to union growth in a non-linear manner, such that higher rates of inflation exert a smaller or greater impact on union growth than lower rates. The results, however, were negative.

24. It could be argued that the features of wage determination that we have described imply that Irish employees have focused their wage bargaining activity on real wages, with the result that any 'credit effect' enjoyed by unions has depended on trends in real rather than money wages. The results obtained when real wage variables are introduced into the preferred model fail to provide support for this hypothesis. Neither $\Delta(\mathrm{W} / \mathrm{P})_{\mathrm{t}}$ or $\Delta \mathrm{W}-\Delta \mathrm{P}_{\mathrm{t}}$ attain significance at the 95 per cent level. The results obtained when $\Delta(\mathrm{W} / \mathrm{P})_{\mathrm{t}}$ is introduced into the model suggested that union growth has benefited from a degree of 'money illusion' or perhaps from the fact that wage rises have proved more salient to some employees than price rises. It should be noted that when an F test is applied to a linear restriction imposed on money wage trends and inflation, the restriction is rejected at the 95 per cent level but cannot be rejected at the 99 per cent level. Similar results are obtained for $\Delta(\mathrm{W} / \mathrm{P}) \mathrm{t}$ and $\Delta \mathrm{W}-\Delta \mathrm{P}_{\mathrm{t}}$.

25. This explanation is not entirely satisfactory, however. While it is certainly plausible that trade union members may have become accustomed to such an expectation, with the result that, other things being equal, they were no more likely to remain union members in times of high inflation than at other times, the bearing of this hypothesis on the propensity of potential members to join unions appears a good deal more remote. The hypothesis may reasonably be extended-though somewhat tenuously - to the behaviour of potential trade union members employed in industries covered by unionized bargaining units. It becomes plausible in other industries only if it can be assumed that pay rises here too were transparently influenced by trends in the cost of living. This seems unlikely but, in any event, cannot be assessed empirically due to the paucity of studies of sectoral developments in Irish industrial relations.

26. In a later analysis of union growth in the UK, Bain and Elsheikh found that the rate of change in real profits had a significant effect on union growth over the period for which data were available (1893-1913 and 1920-65), without altering appreciably the explanatory significance of other terms in their model (see Elsheikh and Bain, 1979).

27. Sapsford and Smyth's specification of profits variables in levels rather than rates of change, however, is open to serious question. Both their money and real profits levels are derived from the national accounts and trend sharply upwards over the period in question in response to growth in the capital base of the Irish economy. As such, profits level variables of this kind are in major part measuring such a time trend rather than the cyclical 'prosperity effect' intended. Thus, it is best to follow Bain and Elsheikh by using a rate of change variable to specify variations in profitability.

28. When (an index of) the level of real profits is used as a regressor over the period 1943-77 it attains significance at the 95 per cent level and the price term in the equation also attains significance at the same level. However, these results seem to be affected by multicollinearity caused by the introduction of the real profits term II/ $/ \mathrm{P}_{\mathrm{t}}$. II $/ \mathrm{P}_{\mathrm{t}}$ is highly correlated with $\Delta \mathrm{P}_{\mathrm{t}}(\mathrm{r}=0.718)$, with $\mathrm{DE}_{\mathrm{t}-\mathrm{t}}(\mathrm{r}=0.791)$ and also with $\Delta \mathrm{W}_{\mathrm{t}}(\mathrm{r}=0.671)$. Each of these variables is significantly less highly correlated with the dependent variable, $\Delta \mathrm{M}_{\mathrm{t}}$. Consistent with these results, the significance of $\mathrm{II}_{t}$ is affected by the exclusion of $\Delta \mathrm{P}_{\mathrm{t}}$ and $\mathrm{DE}_{\mathrm{t}-\mathrm{t}}$ from the estimating equation. Neither Sapsford nor Smyth appear to have considered the possibility that the results obtained when $\mathrm{II} / \mathrm{P}_{\mathrm{t}}$ was introduced into their models were seriously affected by multicollinearity.

29. For a discussion of the issue of wartime migration and of the manner in which it was regarded by Smyth, see Roche and Larragy (1989: 39-40).

30. It might be thought better on theoretical grounds to include a domestic unemployment term in models incorporating either $\mathrm{UI}-\mathrm{UK}_{\mathrm{t}}$ or $\mathrm{MIG}_{\mathrm{t}}$ to separate out the 
effects of domestic unemployment and migration. However, further regressions indicated that the results are not affected by the inclusion of a domestic unemployment term. Nor are they affected by applying one-year lags to $\mathrm{UI}-\mathrm{UK}_{\mathrm{t}}$ or $\mathrm{MIG}_{\mathrm{t}}$.

31. In the light of Smyth's results we tested for the possibility of a structural break in the regime generating union growth at the outset of the War and after the War. However, Chow tests for structural breaks in 1939 and 1946 in our preferred model with the addition of $\mathrm{UI}-\mathrm{UK}_{\mathrm{t}}$ were negative.

32. The beta values on $\Delta W_{t}$ in alternative models tend to fall in the range $0 \cdot 36-0 \cdot 37$.

33. For a fuller development of this theme, see Roche and Larragy (1989: 46-7).

34. A review of national wage bargaining in Ireland during that decade, commissioned by the Federated Union of Employers, concluded that supplementary bargaining was sufficiently widespread to have constituted a second tier of pay bargaining (Fogarty et al., 1981). The case load of the Labour Court also increased dramatically during the $1970 \mathrm{~s}$, partly in response to union claims relating to the anomaly and productivity provisions of successive agreements.

35. When a dummy confined to the 1970's generation of national agreements is tested, it retains a negative sign but is even more insignificant.

\section{REFERENCES}

Armingeon K. (1988): 'Trade Unions under Changing Conditions: the West German Experience', European Sociological Review, 5: 1-23.

Ashenfelter O, Pencavel J H. (1969): 'American Trade Union Growth: 1900-1960', Quarterly Journal of Economics, 83: 434-448.

Bain G S, Elsheikh F. (1976): Union Growth and the Business Cycle, Oxford: Basil Blackwell.

Carruth A, Disney R. (1988): 'Where Have Two Million Trade Union Members Gone?', Economica, 55: 1-20.

Committee on Industrial Organization (1965): Final Report, Dublin: Stationery Office, Pr. 8082.

Conniffe D, Kennedy K A. (1984): Employment and Unemployment Policy for Ireland, Dublin: Economic and Social Research Institute.

Department of Industry and Commerce (1947): The Trend of Employment and Unemployment for 1947, Dublin: Government Publications.

Elsheikh F, Bain G S. (1979): 'The Determination of the Rate of Change of Unionization in the U.K.: A Comment and Further Analysis', Applied Economics, 11: 451-463.

Fogarty M, Egan D, Ryan L. (1981): Pay Policy in the 1980's: A Report, Dublin: Federated Union of Employers.

ITGWU (1947): Annual Report, Dublin: ITGWU.

Kamenta J. (1971): Elements of Econometrics, London: Macmillan.
Kennedy K A. (1971): Productivity and Industrial Growth: The Irish Experience, Oxford: Clarendon Press.

Lewis-Beck M. (1980): Applied Regression: An Introduction, London: Sage Publications.

McAleese D. (1971): Effective Tariffs and the Structure of Industrial Protection in Ireland, Dublin: ESRI Research Paper, No. 62.

McAleese D, Martin J L. (1973): Irish Manufacturing Imports from the United Kingdom in the Sixties: the Effects of AIFTA, Dublin: ESRI Research Paper, No. 79.

O'Brien J F. (1981): A Study of National Wage Agreements in Ireland, Dublin: ESRI Research Paper, No. 104.

O'Donohoe L G. (1982): An Analysis of Trade Union Growth in the Republic of Ireland: 1946-1979, unpublished Master of Business Studies Thesis, Department of Industrial Relations, University College Dublin.

O'Mahony D. (1965): Economic Aspects of Industrial Relations, Dublin: ESRI Research Paper, No. 19.

Ostrom C W. (1978): Time Series Analysis: Regression Techniques, London: Sage Publications.

Pelletier J. (1988): Legal Climate and the Growth of Trade Union Membership: A Comparative Study of the United Kingdom and Ireland, Unpublished, Harvard University Senior Honors Thesis.

Roche W K, Larragy J. (1989): The Determinants of the Annual Rate of Trade Union Growth and Decline in Ireland: Evidence from the DUES Membership Series, University College Dublin and University of Mannheim: DUES Working Papers.

Sapsford D. (1983): 'Trade Union Growth in Ireland', Economics Letters, 12: 89-96.

- (1984): 'The Determinants of Trade Union Growth in the Republic of Ireland', The Economic and Social Review, 15: 305-323.

Schnabel C. (1987): 'Trade Union Growth in the Federal Republic of Germany', Diskussionbeiträge aus dem Institut für Volkswirtschaftslehre, Universität Hohenheim: Stuttgart.

Sharpe I G. (1971): 'The Growth of Australian Trade Unions: 1907-1969', Journal of Industrial Relations, 13: 139-154.

Smyth D J. (1985): 'Trade Union Growth in Ireland and the Interdependence of the Irish and United Kingdom Labour Markets', Economics Letters, 19: 199-202.

Stepina L P, Fiorito J. (1986): 'Toward a Comprehensive Theory of Union Growth and Decline', Industrial Relations, 25: 248-263.

Tomlin B. (1966): The Management of Irish Industry, Dublin: Irish Management Institute.

\section{AUTHORS' ADDRESS}

William K. Roche and Joe Larragy, Department of Industrial Relations, Faculty of Commerce, University College, Belfield, Dublin 4, Ireland.

Manuscript received: April, 1989. 


\section{APPENDIX}

\section{Data Sources and Variable Definitions}

All rate of change variables were defined in the following manner:

$$
\Delta \mathrm{X}_{\mathrm{t}}=\frac{\mathrm{X}_{\mathrm{t}}-\mathrm{X}_{\mathrm{t}-1}}{\mathrm{X}_{\mathrm{t}-1}}
$$

\section{INTERVAL LEVEL VARIABLES}

\section{Trade Union Membership (M)}

Data series constructed in accordance with the principles outlined in detail in W. K. Roche and J. Larragy, 'The Determinants of Annual Trade Union Growth and Decline in the Irish Republic: Evidence from the DUES Membership Series', DUES Working Papers, Department of Industrial Relations, University College Dublin and University of Mannheim, Federal Republic of Germany. The DUES Series on Trade Union Membership in Ireland will be published in J. Visser and B. Ebbinghaus, eds., The Development of Trade Unions in Western European Societies: Data Handbook, Vol. 1 (forthcoming).

\section{Trade Union Density ( $D E$ and $D W F$ )}

Measured as $\mathrm{M} / \mathrm{E}$ or $\mathrm{M} / \mathrm{WF}$, where $\mathrm{E}$ denotes the estimated number of civilian employees at work (see below) and WF denotes $\mathrm{E}$ plus numbers unemployed (see below).

\section{Civilian Employees at Work (E)}

A variety of sources and methods were used to derive estimates of $E$ and thus of $\Delta E$. Again a detailed discussion of how the series was constructed will be found in Roche and Larragy, op. cit. The principles applied in developing the employees at work series are outlined below. From these estimates were subtracted data on numbers in the Gardai and defence forces. Data on numbers of personnel in the permanent defence forces were obtained from The Statistical Abstract (1930-1939), the Department of Defence (19451984) and a variety of other sources (1940-44), principally, Robert Fisk, In Time of War: Ireland, Ulster and the Price of Neutrality 1939-45 (London, Paladin, 1985). Data on the strength of the Gardai were obtained from The Department of Justice (1939-1984) and The Statistical Abstract (1930-38).

(i) Total employees at work 1930-1946: For the period 1930-1950, national health insurance contribution data on employment levels were used as a trend indicator for interpolating and extrapolating data on employment contained in the population censuses of 1936 and 1946 . While such data represent the most comprehensive source of information on the yearly trend in employment during this period, estimates must be treated with caution, given that the coverage of the national health insurance scheme was far from universal. NHI data were published in The Trend of Employment and Unemployment (Dublin, Department of Industry and Commerce).

(ii) Total employees at work 1947-71: Estimates for 1951-70 are taken from G. Hughes, The Functional Distribution of Income in Ireland, 1938-1970 (Dublin, ESRI, 1973), Table A 6. Estimates for the periods $1947-50$ and $1967-71$ were derived by applying the method of trend interpolation outlined in Hughes, op. cit.

(iii) Total employees at work 1972-84: Derived from Employment and Unemployment 1984 (Brussels, Eurostat, 1984) updated from unpublished data made available by the Central Statistics Office.

\section{Unemployment $(U)$}

Data on annual average numbers on the live register (193284), expressed as a percentage rate of the total civilian employee workforce, defined as civilian employees at work (E), plus the live register totals. The data were obtained from the live register tables in The Trend of Employment and Unemployment.

Data on unemployment in the United Kingdom were obtained from Bain and Elsheikh, Union Growth and the Business Cycle, Appendix E, Table E.1, updated by data in G. S. Bain and R. Price, 'Union Growth in Britain: Retrospect and Prospect', British Journal of Industrial Relations, 21, 1983, Table 7 .

\section{The Employee Workforce (WF)}

This was defined as E plus totals on the live register.

\section{Wages (W)}

The earnings series was constructed of necessity from several sources. For the period 1931-39 the only wage series available covered rates per hour paid to wage earners in 23 industrial occupations. As the hours of work of those covered by this early survey did not change to any significant degree over the period, the data are a reasonable indicator of weekly rates. Problems arise, however, in using these data and in regard to their consistency with the data on earnings used for the remainder of the period covered by the study. First of all, the wage rates related, in the words of the survey, to the 'beginning of the year'. As such, it seemed advisable to regard the index rate given for each year as more properly pertaining to the previous year. This procedure was followed in assigning values to the years 1931-39. Second, it might be questioned whether these data on wage rates are consistent with data for the period from 1940 on earnings. Given the under-developed state of collective bargaining during the 1930s and the dominance of industrylevel and district bargaining structures in the period before the Second World War, it seems reasonable to assume that wage rate data is an acceptable measure of the trend in earnings and that no major inconsistency is introduced into the series on this account. The wage rate series was taken from Some Statistics of Wages and Hours of Work in 1937 with Comparative Figures for Certain Previous Years, Dublin, Department of Industry and Commerce, P. No. 2904,1938 . For 1930 we had to rely on secondary sources for an indication of wage trends. On the basis of an economic commentary which indicated that wages had not changed to any significant degree in the Dublin areas during 1930, a value of 0 was assigned to $\Delta \mathrm{W}_{\mathrm{t}}$ for that year. See Report of the Commission on Banking, Currency and Credit, Dublin, Stationery Office, 1938.

For the period 1940-49 data were available on the 'total weekly earnings per wage earner' of wage earners in 'certain industries producing transportable goods'. It was estimated 
that these industries accounted for approximately 80 per cent of employment in the production of transportable goods. An index was derived from these wage data by averaging values in the March and September censuses, reported in The Irish Trade Journal and Statistical Bulletin. (A commentary on the series appears in the March 1943 edition of the ITJSB, p. 11.) Data for the period 1950-84 are based on averaging earnings reported in the quarterly inquiries of all industries producing transportable goods. The data are reported in the ITJSB and The Irish Statistical Bulletin.

\section{Retail Prices $(P)$}

The prices series used in this study were obtained by linking together the cost of living index (1930-47), 'interim cost of living index' (1947-52) and consumer price index (1953-84). The data were obtained from The Irish Trade Journal and Statistical Bulletin and The Irish Statistical Bulletin.

\section{Indicators of Competitiveness $(C)$}

Data on Irish retail price trends were obtained as outlined above. Data on retail prices in the United Kingdom were obtained from Bain and Elsheikh, Union Growth and the Business Cycle, Appendix E, Table E.1, updated from data in G. S. Bain and R. Price, 'Union Growth in Britain: Retrospect and Prospect', Table 7, and ILO International Year Book of Labour Statistics (Geneva, ILO, 1986), p. 380, Table 23. Data on the United Kingdom share of Irish trade were derived by using data on the value at current prices of Irish exports to, and imports from, Great Britain and Northern Ireland (source: The Statistical Abstract). These data were obtained for five-year time-points from 1930 and values for intervening years were derived through linear interpolation. The resulting factors were used as weights on relative price trends. Data on exchange rates of the punt relative to sterling, used to weight the relative price variables to take account of exchange rate variations, relate to annual average exchange rates and are published in The Annual Report of the Central Bank of Ireland, Dublin.

\section{Profits}

Data for the years 1944 to 1984 cover the 'trading profits of companies (including corporate bodies) before tax', obtained from the Irish Statistical Bulletin and National Income and Expenditure (Dublin, Central Statistics Office). The value for 1943 was derived as the predicted value from a linear regression of 'trading profits' on corporation tax returns published in Reports of the Revenue Commissioners (Dublin, Central Statistics Office).

\section{Migration (MIG)}

Estimates of 'net migration' for the period 1930 to 1975 were obtained from J. G. Hughes, Estimates of Annual Net Migration and their Relationship with Series on Annual Net Passenger Movement: Ireland 1926-76 (Dublin, Economic and Social Research Institute, Memorandum Series, August
1977). Estimates for the period 1976 to 1984 were predicted values obtained from a linear regression of estimated migration (1943-74) on net annual passenger movements. Data on annual passenger movements were obtained from Hughes, op. cit. and The Statistical Abstract of Ireland.

Strike activity (WI and variants)

Data on workers involved in strikes and on working days lost due to strikes between 1930 and 1979 were obtained from The Report of the Commission of Inquiry on Industrial Relations (Dublin, Stationery Office, 1981), Appendix 5, Table 3. Data for the remainder of the period were obtained from The Irish Statistical Bulletin.

\section{DUMMY VARIABLES}

Transition effect $(T)$

A detailed account of the construction of this variable is found in the text.

The institutional character of wage bargaining

( $R$ and variants)

Scoring on the reported simple wage-round incidence dummy:

$$
\begin{array}{cc}
\text { Zero } & \text { One } \\
1930-45 ; 1953-54 ; 1963 ; 1965 & 1946-52 ; 1955-62 ; 1964 ; \\
1966-84
\end{array}
$$

The main sources used for information on wage rounds were David O'Mahony, Economic Aspects of Industrial Relations, Dublin, ESRI Paper No. 24, 1965; W. E. J. McCarthy, et al., Wage Inflation and Wage Leadership, Dublin, ESRI Paper No. 79, 1975; J. O'Brien, A Study of National Wage Agreements in Ireland, Dublin, ESRI Research Paper No. 104, 1981; Industrial Relations News Report, published in Dublin by Industrial Relations News.

The level of wage bargaining ( $N$ and variants) Scoring on the reported national wage agreement dummy:

$$
\begin{array}{cc}
\text { Zero } & \text { One } \\
1930-47 ; 1953-56 ; 1959-63 ; & 1948-52 ; 1957-58 ; 1964 ; \\
1965 ; 1968-69 ; 1981-84 & 1966-67 ; 1970-80
\end{array}
$$

The sources are those reported above.

The political composition of Government (Pol and variants) Scoring on the reported political dummy:

$$
\begin{array}{cc}
\text { Zero } & \text { One } \\
1930-31 ; 1933-47 ; 1957-72 ; & 1932 ; 1948-56 ; 1973-76 ; \\
1977-1980 & 1981-84
\end{array}
$$

The sources used were P. Flora et al., State, Economy and Society in Western Europe 1815-1975: A Data Handbook, London, Campus Macmillan, 1983; The Magill Book of Irish Politics, Dublin, Magill Publications. 